\begin{tabular}{|l|l|c|}
\hline$\omega^{5}$ & $\$ 4-99$ & Page 1 of 1 \\
\hline
\end{tabular}

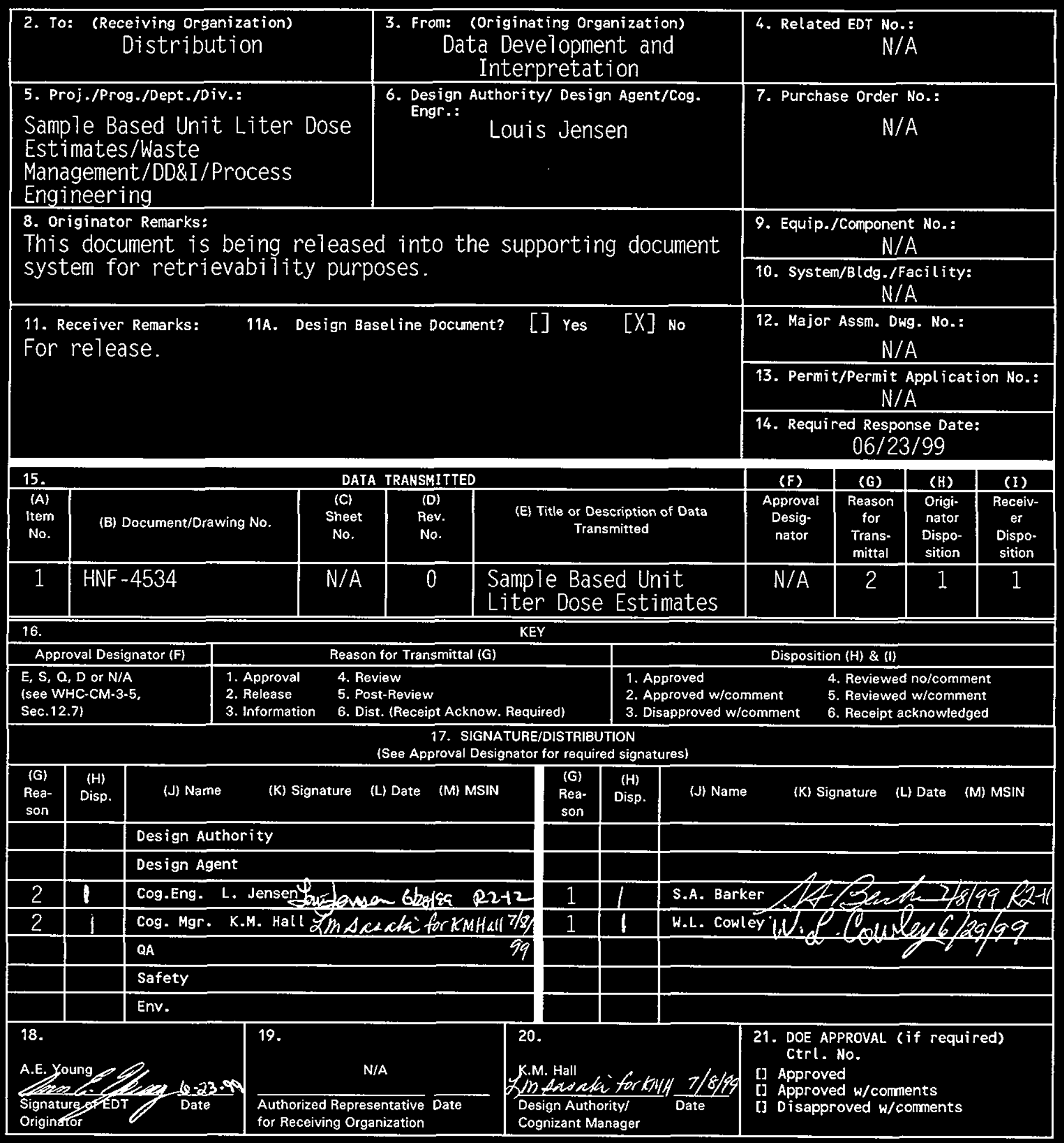

BD-7400-172-2 (05/96) GEF097 
M

\section{Sample Based Unit Liter Dose Estimates}

Louis Jensen, Steven R. Wilmarth

Lockheed Martin Hanford, Corp., Richland, WA 99352

U.S. Department of Energy Contract DE-AC06-96RL13200

$\begin{array}{lll}\text { EDT/ECN: } & \text { EDT-611473 } & \text { UC: } 2070 \\ \text { Org Code: } & 74 B 20 & \text { CACN/COA: 101949/EI00 } \\ \text { B\&R Code: } & \text { EW } 3120074 & \text { Total Pages: } 35\end{array}$

Key Words: Sample Based Unit Liter Dose Estimates, Dose Estimates, Unit Liter Dose Distributions

Abstract: N/A

TRADEMARK DISCLAIMER. Reference herein to any specific commercial product, process, or service by trade name, trademark, manufacturer, or otherwise, does not necessarily constitute or imply its endorsement, recommendation, or favoring by the United States Government or any agency thereof or its contractors or subcontractors.

Printed in the United States of America. To obtain copies of this document, contact: Document Control Services, P.0. Box 950, Mailstop H6-08, Richland WA 99352, Phone (509) 372-2420; Fax (509) 376-4989.
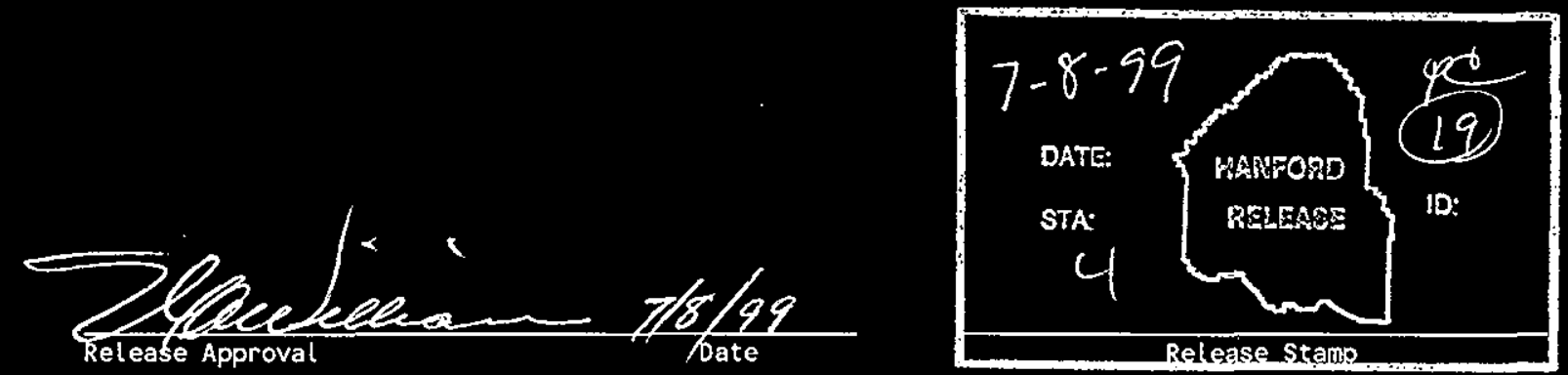

Approved for Public Release 
HNF-4534

Revision 0

\title{
Sample Based Unit Liter Dose Estimates
}

\author{
L. Jensen \\ S. R. Wilmarth \\ Lockheed Martin Hanford Corporation
}

Date Published

July 1999

Prepared for the U. S. Department of Energy

Assistant Secretary for Environmental Management

Project Hanford Management Contractor for the

U.S. Department of Energy under Contract DE-AC06-96RL13200

Approved for public release; distribution is unlimited 


\section{CONTENTS}

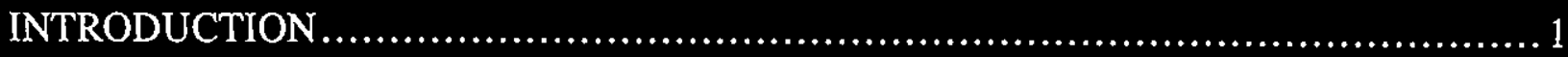

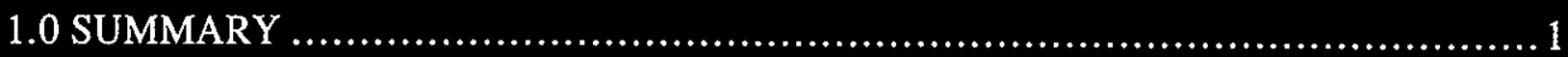

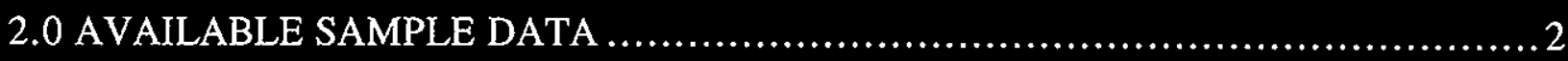

2.1 TANK SPECIFIC RADIOISOTOPE CONCENTRATIONS............................2

2.2 TANK SPECIFIC UNIT LITER DOSE ................................................ 3

3.0 LOGNORMAL DISTRIBUTION ................................................. 4

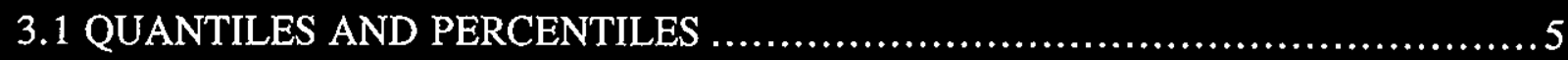

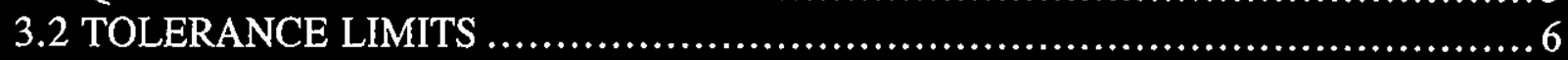

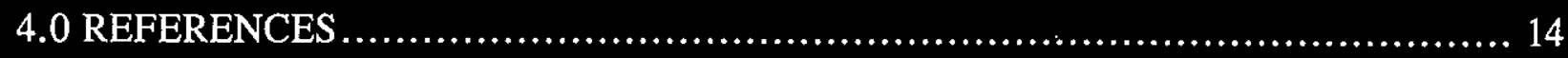

\section{APPENDICES}

APPENDIX A. UNIT LITER DOSE TABLES .....................................A-1

APPENDIX B. INDEPENDENT REVIEW ....................................................... 


\section{LIST OF TABLES}

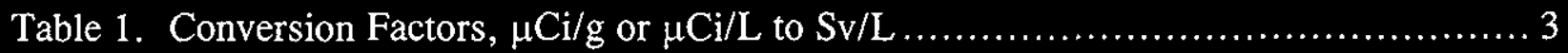

Table 2. Estimates of Means and Variances for the Lognormal Distribution .................. 5

Table 3. Quantiles Corresponding to the $95^{\text {th }}$ and $99^{\text {th }}$ Percentiles of the Lognormal Distribution and the BIO ULD ................................................ 6

Table 4. Values of $\mathrm{K}$ for One-sided 95\% Tolerance Limits ............................... 7

Table 5. One-sided 95\% Tolerance Limits for the Proportion $\mathrm{P}=0.95$ and $\mathrm{P}=0.99$ and the BIO ULD ................................................................... 7

Table A-1. Mean Analyte Concentration ( $\mu \mathrm{Ci} / \mathrm{g})$, SST Solid Samples $\ldots . \ldots \ldots \ldots \ldots \ldots \ldots \ldots$ A-3

Table A-2. Mean Analyte Concentrations $(\mu \mathrm{Ci} / \mathrm{L})$, SST Liquid Samples .................. A-4

Table A-3. Mean Analyte Concentrations $(\mu \mathrm{Ci} / \mathrm{g})$, DST Solid Samples ................... A-5

Table A-4. Mean Analyte Concentrations ( $\mu \mathrm{Ci} / \mathrm{L})$, DST Liquid Samples $\quad . . \ldots \ldots \ldots \ldots \ldots . . . . . . .5$

Table A-5. Sv/L by Analyte and ULD, SST Solid Samples ............................. A-6

Table A-6. Sv/L by Analyte and ULD, SST Liquid Samples ............................ A-8

Table A-7. Sv/L by Analyte and ULD, DST Solid Samples ............................ A-8

Table A-8. Sv/L by Analyte and ULD, DST Liquid Samples .......................... A-9

Table A-9. Comparison of Observed and Estimated ULD Quantiles for SSTs .............A-10

Table A-10. Comparison of Observed and Estimated ULD Quantiles for DSTs ............A-11 
HNF-4534 Rev. 0

\section{LIST OF FIGURES}

Figure 1. ULD Lognormal Density and Histogram, Single-Shell Tank Solid Waste ........... 8

Figure 2. ULD Lognormal Density and Histogram, Single-Shell Tank Liquid Waste .......... 9

Figure 3. ULD Lognormal Density and Histogram, Double-Shell Tank Solid Waste .......... 10

Figure 4. ULD Lognormal Density and Histogram, Double-Shell Tank Liquid Waste ......... 11

Figure 5. ULD Lognormal Density and Histogram, Double-Shell Tank Solid Waste, without AY Tanks

Figure 6. ULD Lognormal Density and Histogram, Double-Shell Tank Liquid Waste, without AY Tanks 13 
HNF-4534 Rev. 0

\section{LIST OF TERMS}

$\begin{array}{ll}\mathrm{Bq} / \mu \mathrm{Ci} & \text { Becquerel per microcurie } \\ \mathrm{BIO} & \text { Basis for Interim Operation } \\ \mathrm{Ci} & \text { Curies } \\ \mathrm{DCF} & \text { dose conversion factor } \\ \mathrm{DST} & \text { double-shell tank } \\ \mathrm{FDH} & \text { Fluor Daniel Hanford, Inc. } \\ \mathrm{FSAR} & \text { Final Safety Analysis Report } \\ \mathrm{g} / \mathrm{L} & \text { grams per liter } \\ \mathrm{NS} \& \mathrm{~L} & \text { Nuclear Safety and Licensing } \\ \mathrm{TL} & \text { tolerance limit } \\ \mu \mathrm{Ci} / \mathrm{g} & \text { microcuries per gram } \\ \mu \mathrm{Ci} / \mathrm{L} & \text { microcuries per liter } \\ \% & \text { percent } \\ \mathrm{SST} & \text { single-shell tank } \\ \mathrm{Sv} / \mathrm{L} & \text { sieverts per liter } \\ \mathrm{Sv} / \mu \mathrm{Ci} & \text { sieverts per microcurie } \\ \mathrm{TCD} & \text { Tank Characterization Database } \\ \mathrm{ULD} & \text { unit liter dose } \\ \text { WHC } & \text { Westinghouse Hanford Company }\end{array}$




\section{INTRODUCTION}

The Tank Waste Characterization Program has taken many core samples, grab samples, and auger samples from the single-shell and double-shell tanks during the past 10 years. Consequently, the amount of sample data available has increased, both in terms of quantity of sample results and the number of tanks characterized. More and better data is available than when the current radiological and toxicological source terms used in the Basis for Interim Operation (BIO) (FDH 1999) and the Final Safety Analysis Report (FSAR) (FDH 1999) were developed.

The Nuclear Safety and Licensing (NS\&L) organization wants to use the new data to upgrade the radiological and toxicological source terms used in the BIO and FSAR. The NS\&L organization requested assistance in developing a statistically based process for developing the source terms. This report describes the statistical techniques used and the assumptions made to support the development of a new radiological source term for liquid and solid wastes stored in single-shell and double-shell tanks.

\subsection{SUMMARY}

Estimates of unit liter doses (ULDs) for waste in the single-shell tanks (SSTs) and double-shell tanks (DSTs) were computed based on recent sampling data from the tanks. The data was obtained from the Tank Characterization Database. There was sufficient data to estimate a ULD for 51 SSTs with solid samples, 20 SSTs with liquid samples, 13 DSTs with solid samples, and 25 DSTs with liquid samples.

If it is assumed that the tanks selected for characterization were selected at random, then the ULDs given in this document are unbiased estimates of the ULDs for all SSTs and DSTs. However, it may not be appropriate to assume that the characterized tanks were chosen at random. Many of the tanks that were selected were chosen because they were known to contain wastes that were of concern to Hanford's unresolved safety questions and safety issues. Consequently, if the data from the characterized tanks are an upper bound for all of the tanks then the ULDs are also an upper bound for all tanks.

The lognormal probability distribution was fit to the ULDs. ULD quantiles corresponding to the $95^{\text {th }}$ and $99^{\text {th }}$ percentiles of the lognormal distribution were computed. The ULDs corresponding to the 95/95 and 95/99 tolerance limits (TLs) were also computed (the interpretation of the TLs are, we are $95 \%$ confident that at least $95 \%$ (99\%)' of the population is less than the limit). The ULD quantiles and TLs are compared to the ULDs for the BIO (FDH 1999). In all six cases, the ULD for the BIO is less than the 95/99 TL. In four of the six cases, the ULD for the BIO is approximately equal to the 95/95 TL. 


\subsection{AVALABLE SAMPLE DATA}

The TCD (Tank Characterization Database) contains the waste characterization data from tank samples obtained since 1989. This database was the source of data used to estimate the ULD for each waste storage tank.

From TCD, all of the data for the following seven isotopes were obtained, ${ }^{137} \mathrm{Cs}$, gross alpha, total alpha (total alpha energy emitted from ${ }^{238} \mathrm{Pu},{ }^{239} \mathrm{Pu},{ }^{240} \mathrm{Pu},{ }^{241} \mathrm{Pu}$ ), ${ }^{241} \mathrm{Am},{ }^{239 / 240} \mathrm{Pu},{ }^{89190} \mathrm{Sr}$, and ${ }^{90} \mathrm{Sr}$. There were a total of 13,132 observations. There were 3,180 observations with the qualifiers "U" and "R." The " $U$ " denotes an observation below the detection limit and an " $R$ " denotes that the observation is unusable. All observations with these two qualifiers were deleted. The remaining 9,943 observations consisted of 2,541 on liquid samples and 7,402 on solid samples. The units are $\mu \mathrm{Ci} / \mathrm{g}$ or $\mu \mathrm{Ci} / \mathrm{L}$. Not every tank had data from each of the seven isotopes.

All observations below detection limits were deleted. Consequently, the quantile estimates in the tables and figures apply to the proportion of the population with analyte concentrations above detection limits.

The ULDs were computed based on the isotopes ${ }^{137} \mathrm{Cs},{ }^{90} \mathrm{Sr}$ and ${ }^{90} \mathrm{Y}$ and on alpha. The validity of this assumption is outlined in section 2.0 and 3.0 of Jensen et al. (1998) and in Table 3 of WHC-SD-WM-SARR-037 (WHC 1996).

\subsection{TANK SPECIFIC RADIOISOTOPE CONCENTRATIONS}

For each tank, the arithmetic mean $(\mu \mathrm{Ci} / \mathrm{g}$ or $\mu \mathrm{Ci} / \mathrm{L})$ of the data for each of the seven isotopes was computed. The data from the different analytical procedures were combined. That is, the data from the water, the acid and the fusion dissolution were combined.

The following methods were used to select the data used in the ULD calculations.

For ${ }^{137} \mathrm{Cs}$ : The mean of the ${ }^{137} \mathrm{Cs}$ data was used.

For alpha: If available, the mean for gross alpha was used. If there was no gross alpha mean, the mean of the total alpha (total alpha energy emitted from ${ }^{238} \mathrm{Pu},{ }^{239} \mathrm{Pu},{ }^{240} \mathrm{Pu},{ }^{241} \mathrm{Pu}$ ) was used. If there were means for both gross alpha and total alpha, the mean of the combined data was used. If there was no mean for gross alpha or total alpha, the mean from ${ }^{241} \mathrm{Am}$ was used. If there was no mean for gross alpha or total alpha or ${ }^{241} \mathrm{Am}$, the mean from ${ }^{239 / 240} \mathrm{Pu}$ was used.

For ${ }^{90} \mathrm{Sr}$ : If available, the mean for ${ }^{89190} \mathrm{Sr}$ was used. If there was no mean for ${ }^{89190} \mathrm{Sr}$, the mean for ${ }^{90} \mathrm{Sr}$ was used. If there was a mean for both ${ }^{89190} \mathrm{Sr}$ and ${ }^{90} \mathrm{Sr}$, the mean of the combined data was used. 
To be included in the ULD computations a tank had to have a mean for ${ }^{137} \mathrm{Cs}$, for alpha, and for ${ }^{90} \mathrm{Sr}$. There were 51 SSTs with the three means for solid samples and 20 with the three means for liquid samples. For the DSTs, there were 13 tanks with the three means from solid samples and 25 with means from liquid samples. Tables A-1, A-2, A-3, and A-4 in Appendix A list the three means.

There are a total of 149 SSTs and 28 DSTs and the ULDs can only be estimated for a subset of the total number of tanks. The estimates of the ULDs given in this document are unbiased estimates of the ULDs for all SSTs and DSTs if it is assumed that the tanks with a mean for ${ }^{137} \mathrm{Cs}$, for alpha, and for ${ }^{90} \mathrm{Sr}$ (Tables A-1 through A-4) are a random sample of the tanks. Alternatively, if it is assumed that the tanks with a mean for ${ }^{137} \mathrm{Cs}$, for alpha, and for ${ }^{90} \mathrm{Sr}$ are an upper bound to the means for all of the other tanks then the ULDs based on the sampled tanks are an upper bound for the ULDs for all tanks.

\subsection{TANK SPECIFIC UNIT LITER DOSE}

The units of the means in Tables A-1, A-2, A-3, and A-4 are $\mu \mathrm{Ci} / \mathrm{g}$ or $\mu \mathrm{Ci} / \mathrm{L}$. The units for the ULD are Sv/L (sieverts per liter). The conversions factors used are given in Table 1. The third row of this table are the dose conversion factors (DCF) for ${ }^{137} \mathrm{Cs}$, alpha and ${ }^{90} \mathrm{Sr}$. It is assumed that the concentration for ${ }^{90} \mathrm{Y}$ is the same as that for ${ }^{90} \mathrm{Sr}$.

Table 1. Conversion Factors, $\mu \mathrm{Ci} / \mathrm{g}$ or $\mu \mathrm{Ci} / \mathrm{L}$ to $\mathrm{Sv} / \mathrm{L}$

\begin{tabular}{|c|c|c|c|c|}
\hline 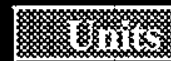 & 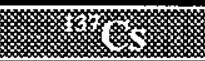 & 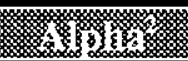 & (5) & 2 \\
\hline $\mathrm{Bg} / \mu \mathrm{Ci}$ & $3.70 \mathrm{E}+04$ & $3.70 E+04$ & $3.70 \mathrm{E}+04$ & $3.70 E+04$ \\
\hline $\mathrm{g} / \mathrm{L}^{3}$ & $1.60 \mathrm{E}+03$ & $1.60 E+03$ & $1.60 \mathrm{E}+03$ & $1.60 \mathrm{E}+03$ \\
\hline $\mathrm{Sv} / \mathrm{Bq}^{1}$ & $8.63 \mathrm{E}-09$ & $1.20 \mathrm{E}-04$ & 6.47E-08 & $2.28 \mathrm{E}-09$ \\
\hline
\end{tabular}

${ }^{1}$ The DCF for Sv/Bq are reported on page 10 of the Attachment to CO-TWRS-154 (Brevick 1999).

${ }^{2}$ It is assumed that alpha is all from ${ }^{241} \mathrm{Am}$.

${ }^{3}$ The conversion $\mathrm{g} / \mathrm{L}$ from a weight basis to a liquid basis is given on page 7 of Brevick et al. (1996).

For solid samples, the equations used to convert $\mu \mathrm{Ci} / \mathrm{g}$ to $\mathrm{Sv} / \mathrm{L}$ are

$$
\begin{aligned}
& \mathrm{Sv} / \mathrm{L}\left({ }^{137} \mathrm{Cs}\right)=\operatorname{mean}\left({ }^{137} \mathrm{Cs}\right) \times(3.70 \mathrm{E}+04) \times(1.60 \mathrm{E}+03) \times(8.63 \mathrm{E}-09) \\
& \mathrm{Sv} / \mathrm{L}(\text { alpha })=\operatorname{mean}(\text { alpha }) \times(3.70 \mathrm{E}+04) \times(1.60 \mathrm{E}+03) \times(1.20 \mathrm{E}-04) \\
& \mathrm{Sv} / \mathrm{L}\left({ }^{90} \mathrm{Sr}+{ }^{90} \mathrm{Y}\right)=\operatorname{mean}\left({ }^{90} \mathrm{Sr}\right) \times(3.70 \mathrm{E}+04) \times(1.60 \mathrm{E}+03) \times(6.47 \mathrm{E}-08+2.28 \mathrm{E}-09) .
\end{aligned}
$$


For liquid samples, the equations used to convert $\mu \mathrm{Ci} / \mathrm{L}$ to $\mathrm{Sv} / \mathrm{L}$ are

$$
\begin{aligned}
& \mathrm{Sv} / \mathrm{L}\left({ }^{137} \mathrm{Cs}\right)=\operatorname{mean}\left({ }^{137} \mathrm{Cs}\right) \times(3.70 \mathrm{E}+04) \times(8.63 \mathrm{E}-09) \\
& \mathrm{Sv} / \mathrm{L}(\text { alpha })=\text { mean }(\text { alpha }) \times(3.70 \mathrm{E}+04) \times(1.20 \mathrm{E}-04) \\
& \mathrm{Sv} / \mathrm{L}\left({ }^{90} \mathrm{Sr}+{ }^{90} \mathrm{Y}\right)=\operatorname{mean}\left({ }^{90} \mathrm{Sr}\right) \times(3.70 \mathrm{E}+04) \times(6.47 \mathrm{E}-08+2.28 \mathrm{E}-09)
\end{aligned}
$$

The ULD is defined to be the sum of the Sv/L for the four isotopes. For each tank and waste type, Tables A-5, A-6, A-7, and A-8 report the individual Sv/L and the ULD. ULDs for tanks 241-AY-101 and 241-AY-102 are included in Tables A-7 and A-8. These two tanks are "aging waste tanks." In the computations, the ULDs for these two tanks are treated separately. Tanks 241-AZ-101 and 241-AZ-102 are also "aging waste tanks." It was not possible to compute a ULD for these two tanks using data from TCD.

\subsection{LOGNORMAL DISTRIBUTION}

Three probability distributions were fit to the ULD data, a lognormal, a gamma, and a Weibull. A goodness-of-fit test was used to test the appropriateness of the three distributions. Based on the goodness-of-fit test, the lognormal distribution cannot be rejected, but the gamma and Weibull distributions are rejected. These three distributions were also fit to ULDs used in the gas release event safety analysis tool (Jensen et al. 1998). For that project, the lognormal distribution was the recommended distribution. In addition, tolerance limits can be computed for the lognormal distribution. They cannot be computed for gamma or Weibull distributions (tolerance limits are discussed in Section 3.2). To be consistent with Jensen et al. (1998) and since the lognormal distribution cannot be rejected, a lognormal distribution is the recommended distribution for the ULDs.

The lognormal distribution is defined as follows. A random variable $\mathrm{X}$ has a lognormal distribution if $\mathrm{Y}=\log (\mathrm{X})$ has a normal distribution. The lognormal density function has the form

$$
\begin{gathered}
f(x)=\frac{1}{x \sqrt{2 \pi} \sigma} \exp \left\{-\frac{(\log (x)-\mu)^{2}}{2 \sigma^{2}}\right\}, x>0 \\
=0, x \leq 0
\end{gathered}
$$

where $\mu$ is the mean of $Y=\log (X)$ and $\sigma^{2}$ is the variance of $Y=\log (X)$. The unbiased estimates of $\mu$ and $\sigma^{2}$ are the sample mean, $\hat{\mu}$, and sample variance, $\hat{\sigma}^{2}$, on the natural log 
scale. Table 2 gives the estimates of the means and variances for the six types of samples. The individual ULDs are given in Tables A-5 through A-8.

Table 2. Estimates of Means and Variances for the Lognormal Distribution

\begin{tabular}{|l|c|c|}
\hline \multicolumn{1}{|c|}{ Type of sample } & $\hat{\mu}$ & $\hat{\sigma}^{2}$ \\
\hline SST solid samples & $7.82 \mathrm{E}+00$ & $2.72 \mathrm{E}+00$ \\
\hline SST liquid samples & $4.87 \mathrm{E}+00$ & $3.50 \mathrm{E}+00$ \\
\hline DST solid samples & $8.50 \mathrm{E}+00$ & $4.26 \mathrm{E}+00$ \\
\hline DST liquid samples & $4.09 \mathrm{E}+00$ & $3.77 \mathrm{E}+00$ \\
\hline DST solid samples without AY tanks & $7.88 \mathrm{E}+00$ & $2.09 \mathrm{E}+00$ \\
\hline DST liquid samples without AY tanks & $4.11 \mathrm{E}+00$ & $3.76 \mathrm{E}+00$ \\
\hline
\end{tabular}

The Kolmogorov-Smirnov goodness-of-fit test was used to determine the appropriateness of the lognormal, the gamma and the Weibull distribution. Based on this test, the lognormal distribution cannot be rejected for each of the six types of waste listed in Table 2. However, the gamma distribution is rejected for the SST solid and liquid samples and the Weibull distribution is rejected for the SST liquid samples. The level of significance of the goodnessof-fit tests was 0.05 .

Figures 1 through 6 are plots of the lognormal density functions for the six types of waste listed in Table 2. Superimposed on these plots are histograms of the corresponding ULDs. A probability density function is non-negative and integrates to one. The lognormal density functions, Figures 1 through 6 , do not integrate to one. They have been normalized so that they can be viewed when superimposed on the histograms.

\subsection{QUANTILES AND PERCENTILES}

The ULDs in the BIO (FDH 1999), for the six types of waste, need to be compared to the quantiles corresponding to the $95^{\text {th }}$ and $99^{\text {th }}$ percentiles of the lognormal distributions. Table 3 lists these quantiles. The quantiles are the ULD values such that $95 \%$ or $99 \%$ of the "population" is to the left of the value. The quantiles are also given in Figures 1 through 6 . A more complete list of the quantiles, and a comparison with the observed, is given in Table A-9 and A-10 in Appendix A. Table 3 also lists the ULDs for the BIO (FDH 1999). The BIO ULD is greater than or approximately equal to the quantile corresponding to the $99^{\text {th }}$ percentiles of the lognormal distribution for each of the six types of waste. 
Table 3. Quantiles Corresponding to the $95^{\text {th }}$ and $99^{\text {th }}$ Percentiles of the Lognormal Distribution and the BIO ULD

\begin{tabular}{|l|c|c|c|}
\hline \multicolumn{1}{|c|}{ Type of sample } & $\mathbf{9 5}^{\text {th }}$ & $\mathbf{9 9}^{\text {th }}$ & BIO \\
\hline SST solid samples & $3.75 \mathrm{E}+04$ & $1.15 \mathrm{E}+05$ & $2.20 \mathrm{E}+05$ \\
\hline SST liquid samples & $2.83 \mathrm{E}+03$ & $1.01 \mathrm{E}+04$ & $1.10 \mathrm{E}+04$ \\
\hline DST solid samples & $1.47 \mathrm{E}+05$ & $6.01 \mathrm{E}+05$ & $5.30 \mathrm{E}+05$ \\
\hline DST liquid samples & $1.46 \mathrm{E}+03$ & $5.50 \mathrm{E}+03$ & $6.10 \mathrm{E}+03$ \\
\hline $\begin{array}{l}\text { DST solid samples without } \\
\text { AY tanks }\end{array}$ & $2.86 \mathrm{E}+04$ & $7.67 \mathrm{E}+04$ & $5.30 \mathrm{E}+05$ \\
\hline $\begin{array}{l}\text { DST liquid samples without } \\
\text { AY tanks }\end{array}$ & $1.49 \mathrm{E}+03$ & $5.61 \mathrm{E}+03$ & $6.10 \mathrm{E}+03$ \\
\hline
\end{tabular}

These quantiles should be used with caution. The reason is that the lognormal density functions are bases on estimates of the means and variances. These estimates are subject to variability and this variability is not incorporated into the estimates of the quantiles. It is difficult to compute confidence statements for the quantiles and for the density functions. However, tolerance limits are similar to quantiles and they incorporate the uncertainty due to using estimates of the means and variances. Tolerance limits may be more appropriate than the quantiles. They are discussed in the next section.

\subsection{TOLERANCE LIMITS}

A one-sided tolerance interval is a confidence statement regarding the proportion of the population below a given limit. The advantage of using TLs is that a confidence statement is part of the TL; i.e., measures of uncertainty are in a TL and they are not in the quantiles. These limits are based on the normal distribution. The limits are of the form $\hat{\mu}+\mathrm{K} \hat{\sigma}$ where $\hat{\mu}$ and $\hat{\sigma}$ are the sample mean and standard deviation on the log scale. The values of $\mathrm{K}$ are tabulated (e.g. Table A-7 in Natrella 1963), they are a function of the number of observations, the confidence level and the proportion. The value $\exp (\hat{\mu}+\mathrm{K} \hat{\sigma})$ is the tolerance limit for the lognormal distribution.

The notation for a $95 \% \mathrm{TL}$ is $95 / \mathrm{P}$ were $\mathrm{P}$ is the proportion of the population. The interpretation of the tolerance interval is that we are $95 \%$ confident that at least P\% of the population (distribution) is below the limit $\exp (\hat{\mu}+\mathrm{K} \hat{\sigma})$. Table 4 gives the values of $\mathrm{K}$ used to compute the 95/95 and 95/99 TLs. The TLs and the ULD for the BIO (FDH 1999) are given in Table 5. Figures 1 through 6 also plot the TLs and the ULD for the BIO (FDH 1999) for the specific type of waste. 
Table 4. Values of $\mathbf{K}^{1}$ for One-sided $95 \%$ Tolerance Limits

\begin{tabular}{|l|c|c|c|c|c|c|}
\hline & \multicolumn{6}{|c|}{ Number of Observations } \\
\hline Proportion & 11 & 13 & 20 & 23 & 25 & 51 \\
\hline $\mathrm{P}=0.95$ & 2.815 & 2.670 & 2.396 & 2.329 & 2.292 & 2.060 \\
\hline $\mathrm{P}=0.99$ & 3.852 & 3.659 & 3.295 & 3.206 & 3.158 & 2.850 \\
\hline
\end{tabular}

${ }^{1}$ Natrelia (1963), page T-15.

Table 5. One-sided 95\% Tolerance Limits for the Proportion $P=0.95$ and $P=0.99$ and the BIO ULD

\begin{tabular}{|l|c|c|c|}
\hline \multicolumn{1}{|c|}{ Type of sample } & 95/95 TL & 95/99 TL & BIO \\
\hline SST solid samples & $7.44 \mathrm{E}+04$ & $2.73 \mathrm{E}+05$ & $2.20 \mathrm{E}+05$ \\
\hline SST liquid samples & $1.16 \mathrm{E}+04$ & $6.22 \mathrm{E}+04$ & $1.10 \mathrm{E}+04$ \\
\hline DST solid samples & $1.22 \mathrm{E}+06$ & $9.39 \mathrm{E}+06$ & $5.30 \mathrm{E}+05$ \\
\hline DST liquid samples & $5.15 \mathrm{E}+03$ & $2.77 \mathrm{E}+04$ & $6.10 \mathrm{E}+03$ \\
\hline $\begin{array}{l}\text { DST solid samples } \\
\text { without AY tanks }\end{array}$ & $1.56 \mathrm{E}+05$ & $6.97 \mathrm{E}+05$ & $5.30 \mathrm{E}+05$ \\
\hline $\begin{array}{l}\text { DST liquid samples } \\
\text { without AY tanks }\end{array}$ & $5.64 \mathrm{E}+03$ & $3.09 \mathrm{E}+04$ & $6.10 \mathrm{E}+03$ \\
\hline
\end{tabular}

The ULD for the BIO is less than the 95/99 TL for all of the waste types. The ULD for the BIO is approximately equal to the 95/95 TL except for the SST solid waste and the DST solid waste without the two AY tanks.

Figures 3 and 4 are the plots of the lognormal distributions for solid and liquid samples for DSTs including tanks 241-AY-101 and 241-AY-102. Figures 5 and 6 are the corresponding plots without the two AY tanks. There is little difference between the two plots for the DST liquid samples. There is a big difference between the two plots for the DST solid samples. The reason for the difference is that ULDs for the solid portion of waste from 241-AY-101 and 241-AY-102 are larger than the other ULDs.

All of the statistical computations and figures were completed using the statistical program S-PLUS (1997). 
HNF-4534 Rev. 0

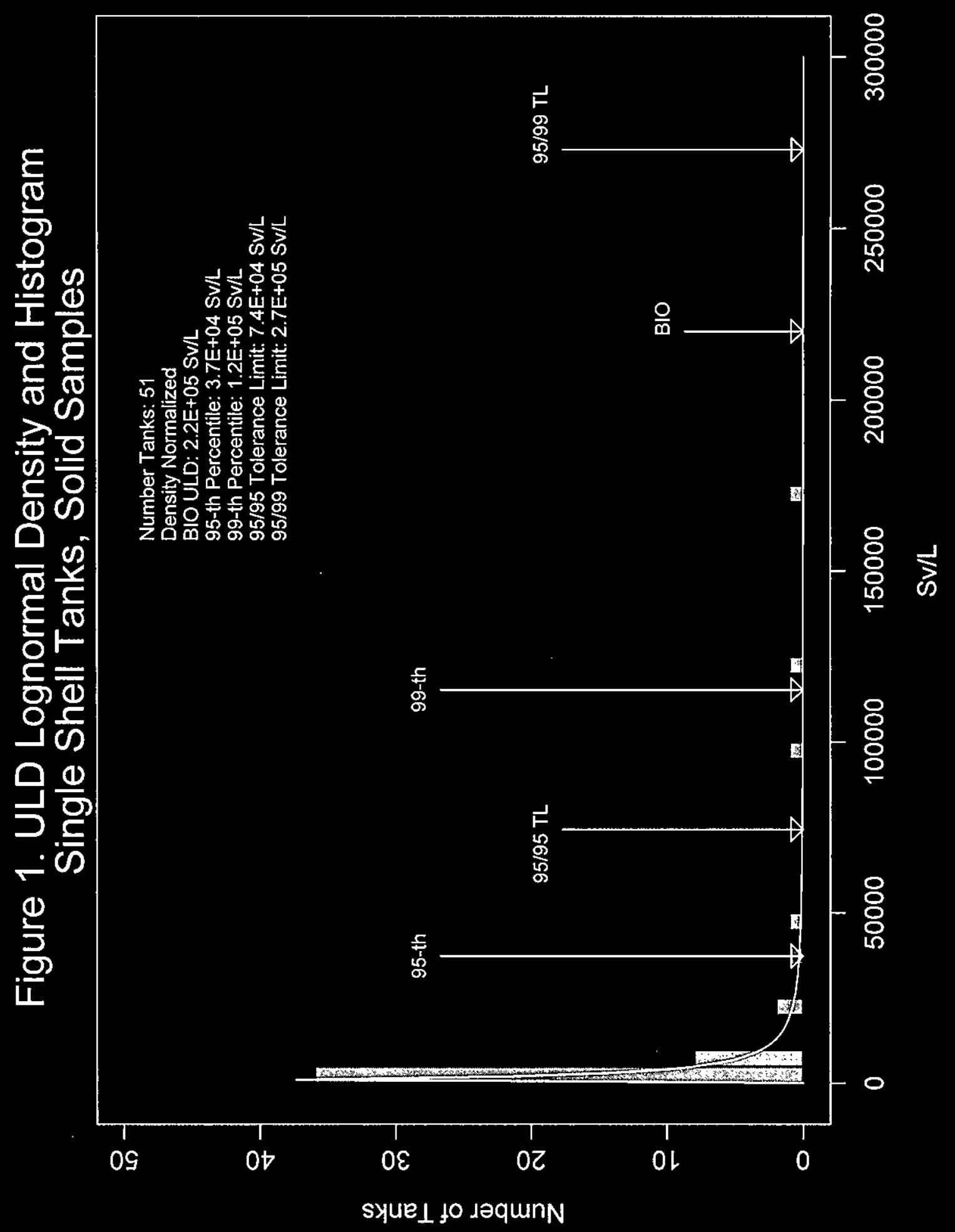




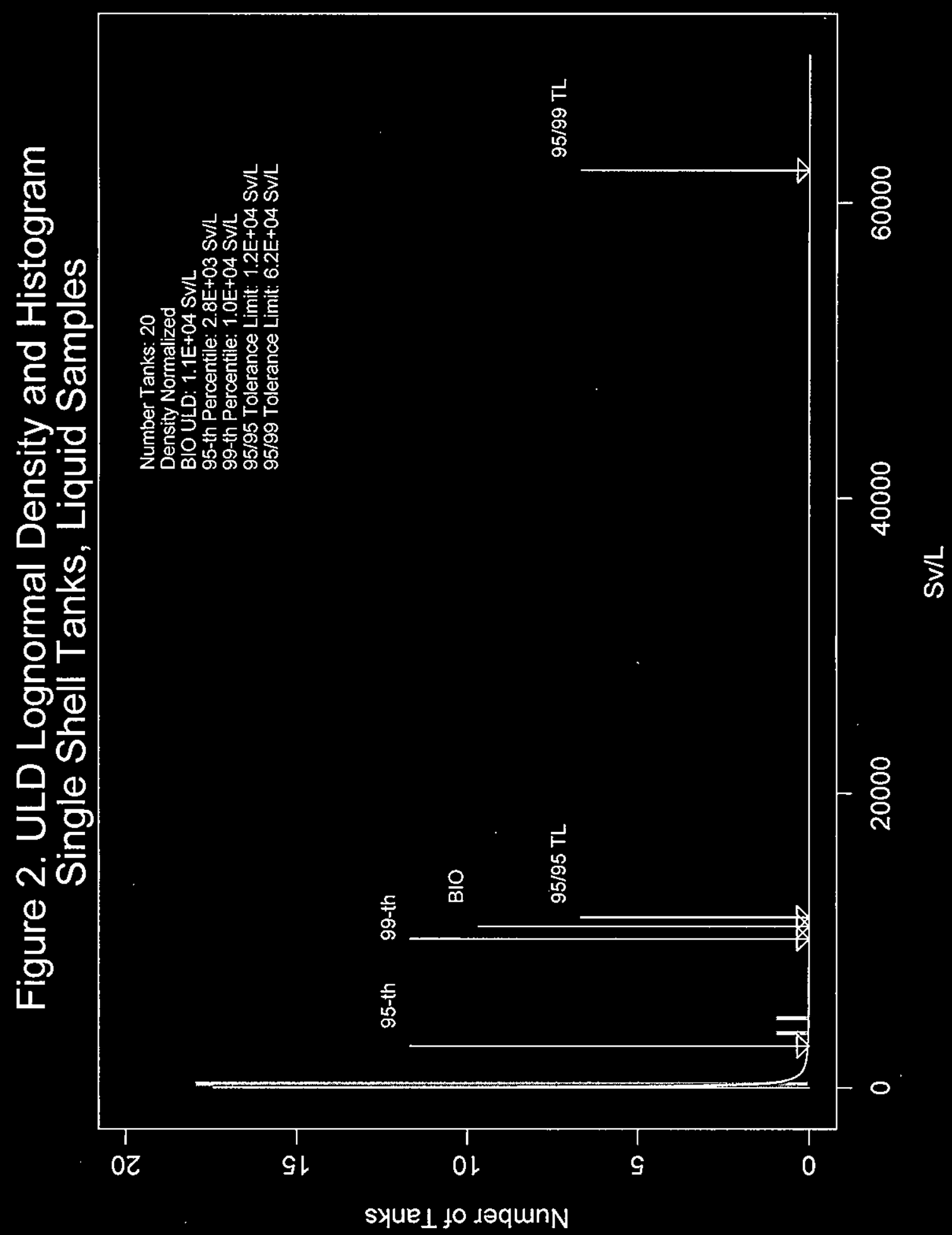




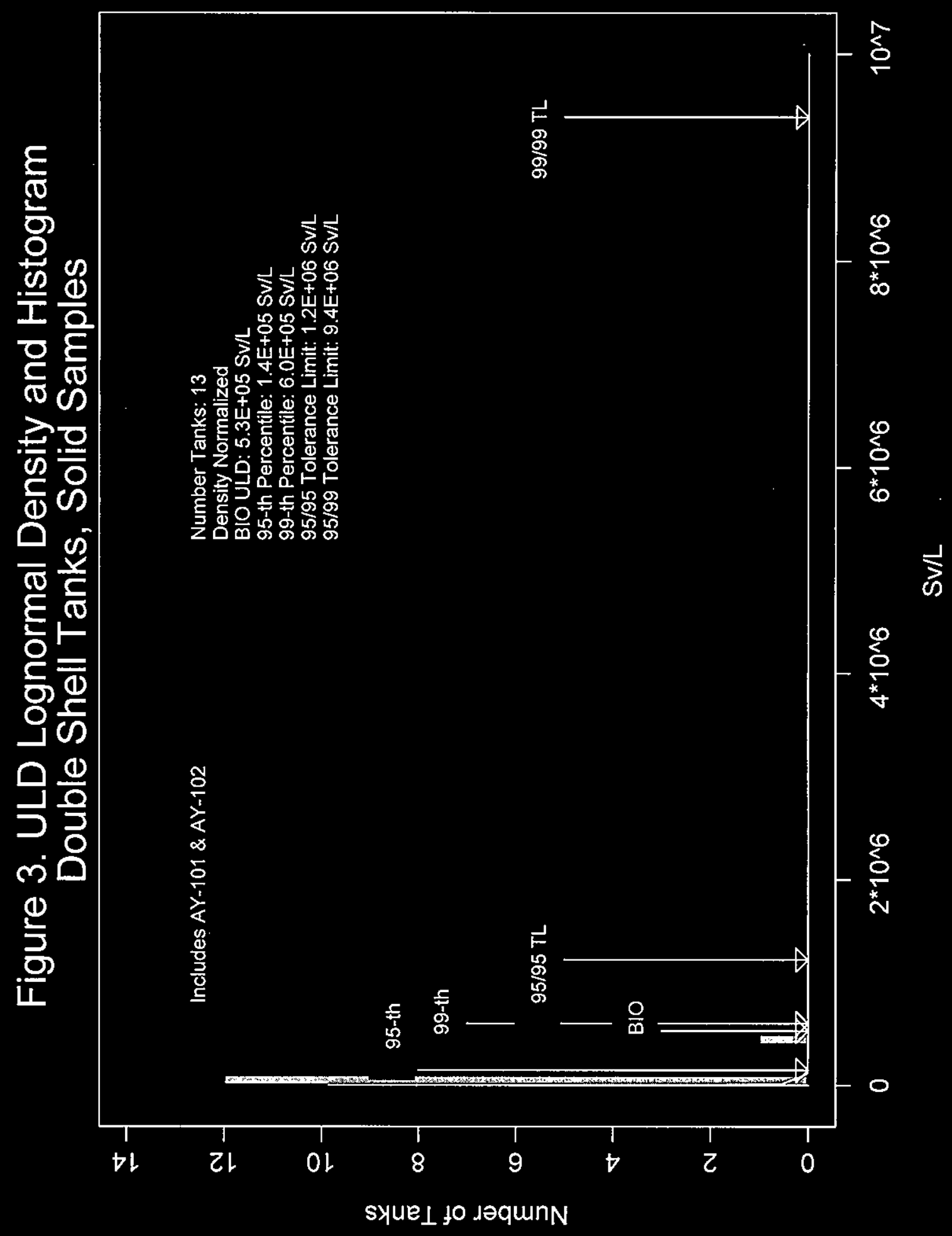


HNF-4534 Rev. 0

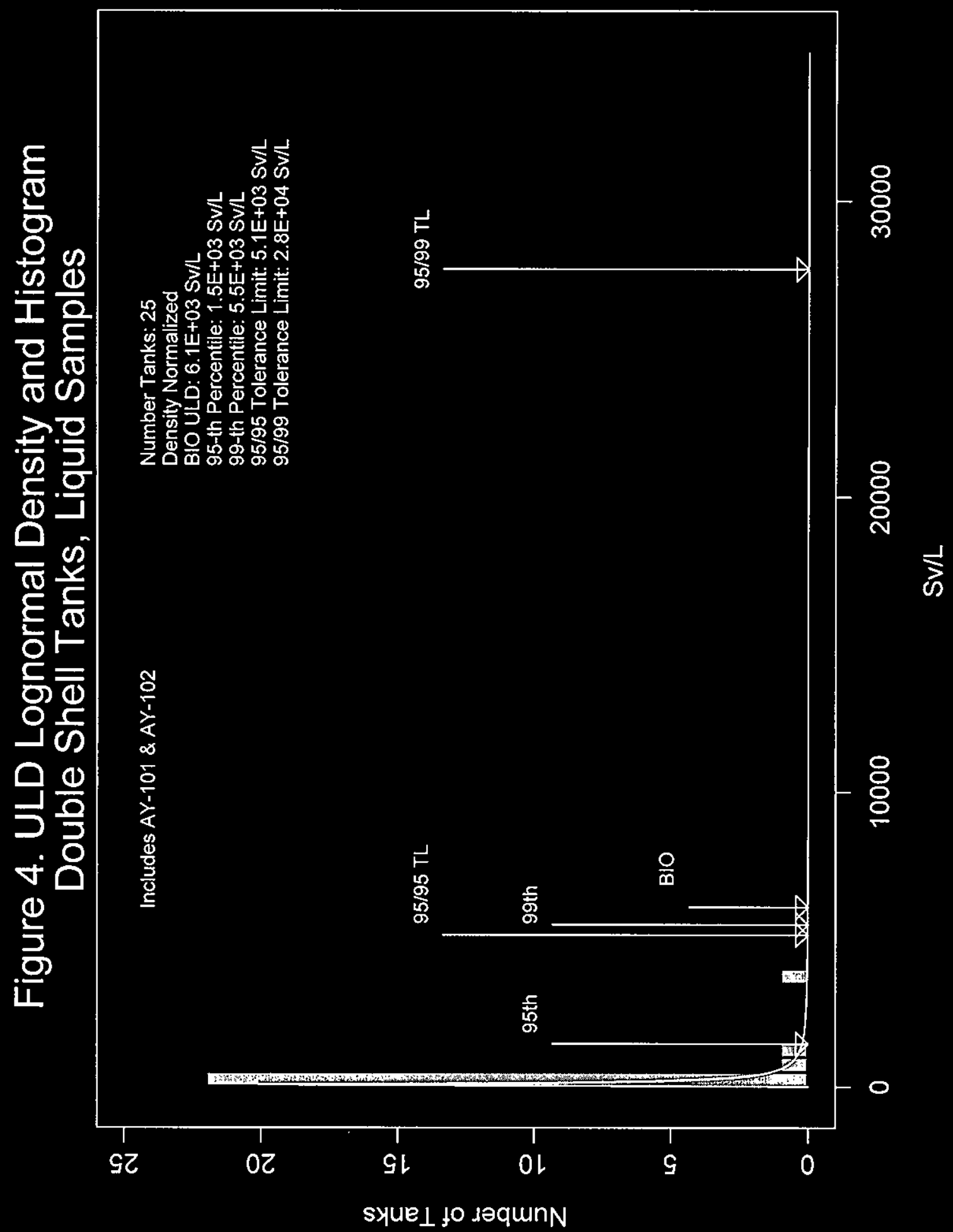




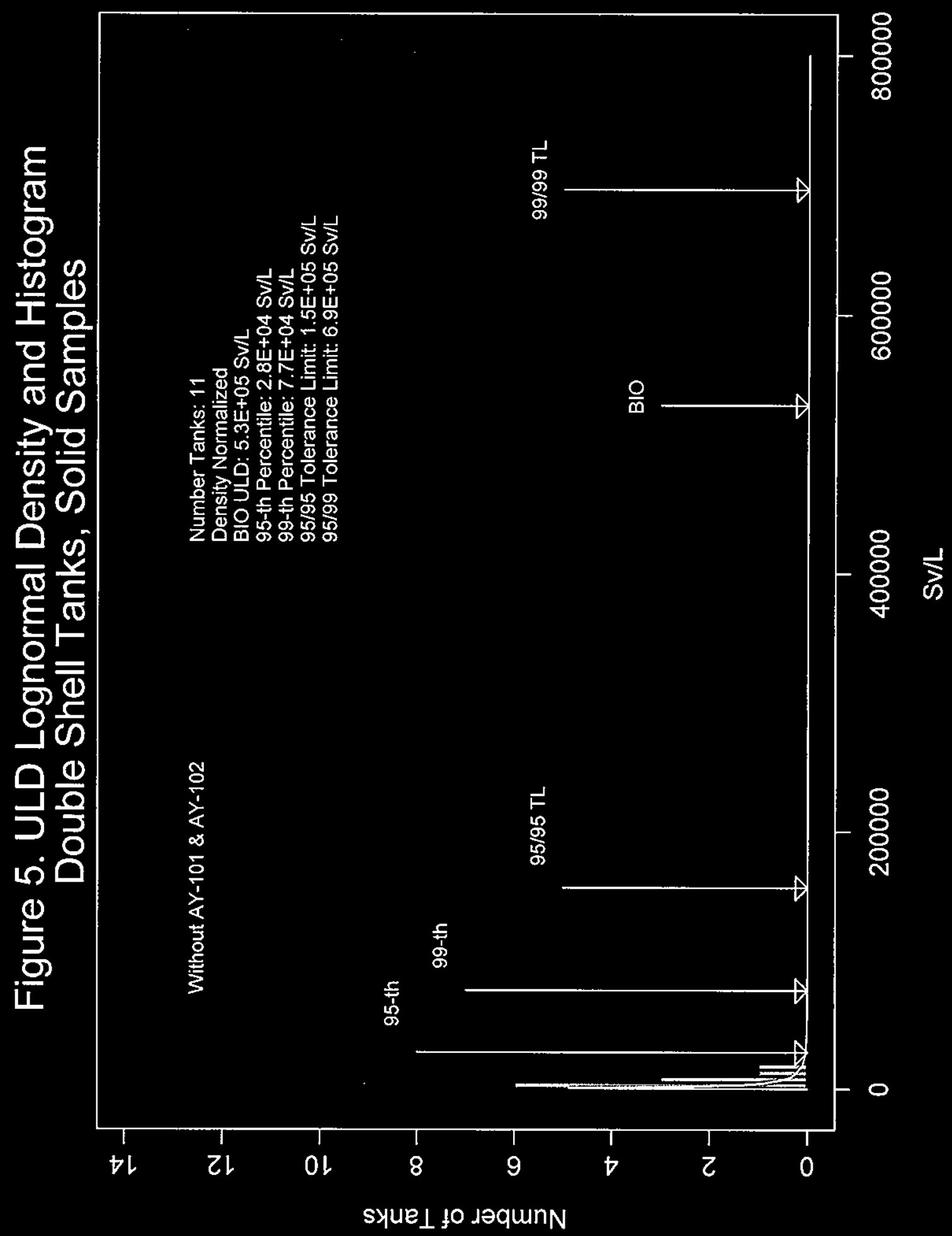




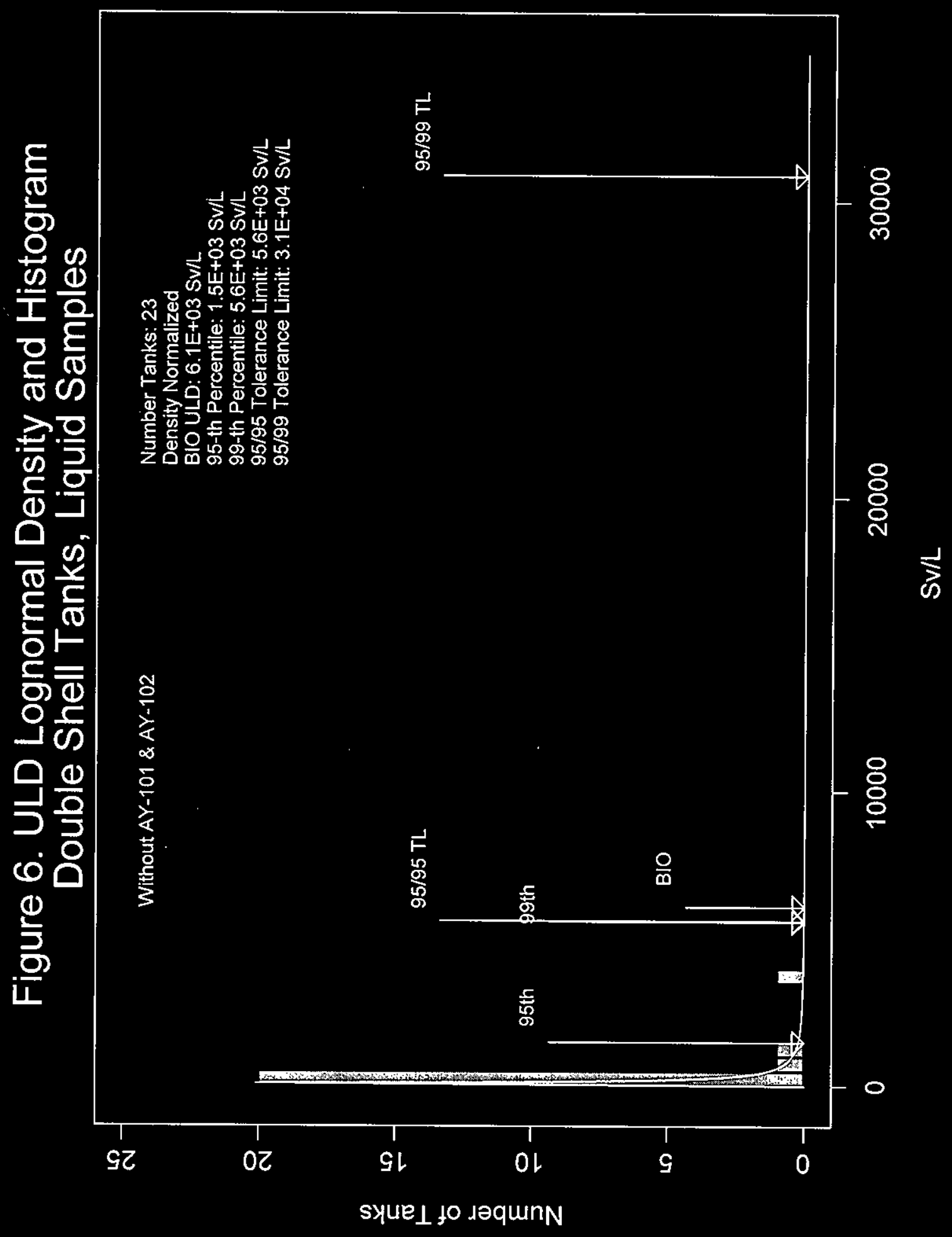




\subsection{REFERENCES}

Brevick, C. H., 1999, Attachment to CO-TWRS-154, (internal memorandum LMHC96WO-0006, CO-99-TWRS to D. A. Reynolds, January 13), Fluor Daniel Northwest, Richland, Washington. .

Brevick, C. H., L. A. Gaddis, and E. D. Johnson, 1996, Tank Waste Source Term Inventory Validation, WHC-SD-WM-ER-400, Rev. 0-A, Westinghouse Hanford Company, Richland, Washington

FDH, 1999, Tank Waste Remediation System Basis for Interim Operation, HNF-SD-WM-BIO-001, Revision 1-C, Fluor Daniel Hanford, Inc., Richland, Washington.

FDH, 1999, Tank Waste Remediation System Final Safety Analysis Report, HNF-SD-WM-SAR-067, Rev. 0, Duke Engineering and Services Hanford, Richland, Washington.

Jensen, L., S.R. Wilmarth and J. M. Grigsby, November 1998, Sample Based Unit Liter Dose Estimates for Use in the Gas Release Event Safety Analysis Tool, HNF-2589, Rev. 0, Fluor Daniel Hanford, Inc., Richland, Washington.

Natrella, M. G., 1963, Experimental Statistics, National Bureau of Standards Handbook 91, U. S. Department of Commerce.

S-PLUS, 1997, Data Analysis Produces Division, MathSoft, Seattle, Washington.

WHC, 1996, Development of Radiological Concentrations and Unit Liter Doses for TWRS FSAR Radiological Consequence Calculations, WHC-SD-WM-SARR-037, Revision 0, Westinghouse Hanford Company, Richland, Washington. 
HNF-4534 Rev. 0

\section{APPENDIX A}

\section{UNIT LITER DOSE TABLES}

In Tables $\mathrm{A} 1, \mathrm{~A} 2, \mathrm{~A} 3$, and $\mathrm{A} 4$, the columns labeled "analyte" denote the type of data used to estimate the mean. That is, ${ }^{137} \mathrm{Cs}$ indicates that the mean of all the ${ }^{137} \mathrm{Cs}$ data for the tank is reported. For alpha, GA indicates that the mean of the gross alpha data is reported; TA, the mean of the total alpha data; GA\&TA, the mean of the combined GA and TA data; ${ }^{241} \mathrm{Am}$, the mean of the ${ }^{241} \mathrm{Am}$ data; and ${ }^{239 / 240} \mathrm{Pu}$, the mean of the ${ }^{239 / 240} \mathrm{Pu}$ data. For strontium, ${ }^{89190} \mathrm{Sr}$ indicates that the mean of ${ }^{89190} \mathrm{Sr}$ is reported; ${ }^{90} \mathrm{Sr}$, the mean of ${ }^{90} \mathrm{Sr}$ data; ${ }^{80 / 90} \mathrm{Sr} \&{ }^{90} \mathrm{Sr}$, the mean of the combined ${ }^{89 / 90} \mathrm{Sr}$ and ${ }^{90} \mathrm{Sr}$ data. 
Table A-1. Mean Analyte Concentration ( $\mu \mathrm{Ci} / \mathrm{g})$, SST Solid Samples (2 Sheets)

\begin{tabular}{|c|c|c|c|c|c|c|}
\hline Tank & Analyte & Mean & Analyte & Mean & Analyte & Mean \\
\hline $241-\mathrm{A}-101$ & ${ }^{137} \mathrm{Cs}$ & $2.03 \mathrm{E}+02$ & GA & $6.15 \mathrm{E}-02$ & ${ }^{89190} \mathrm{Sr}$ & $1.55 \mathrm{E}+01$ \\
\hline 241-AX-101 & ${ }^{137} \mathrm{Cs}$ & $1.99 \mathrm{E}+02$ & GA & $5.17 \mathrm{E}-02$ & ${ }^{89 / 190} \mathrm{Sr}$ & $1.82 \mathrm{E}+01$ \\
\hline 241-AX-104 & ${ }^{137} \mathrm{Cs}$ & $6.07 \mathrm{E}+02$ & GA & $1.38 \mathrm{E}+01$ & ${ }^{89900} \mathrm{Sr}$ & $1.88 \mathrm{E}+04$ \\
\hline 241-B-106 & ${ }^{137} \mathrm{Cs}$ & $2.03 \mathrm{E}+01$ & $\overline{\mathrm{GA}}$ & $4.92 \mathrm{E}-02$ & ${ }^{89190} \mathrm{Sr}$ & $7.18 \mathrm{E}+01$ \\
\hline 241-B-108 & ${ }^{137} \mathrm{Cs}$ & $1.72 \mathrm{E}+01$ & GA & $7.90 \mathrm{E}-03$ & ${ }^{8990} \mathrm{Sr}$ & $2.87 \mathrm{E}+00$ \\
\hline $241-\mathrm{B}-111$ & ${ }^{137} \mathrm{Cs}$ & $1.49 \mathrm{E}+02$ & GA\&TA & $1.24 \mathrm{E}-01$ & ${ }^{90} \mathrm{Sr}$ & $2.48 \mathrm{E}+02$ \\
\hline 241-B-201 & ${ }^{137} \mathrm{Cs}$ & $4.59 \mathrm{E}+00$ & GA\&TA & $1.06 \mathrm{E}+00$ & ${ }^{90} \mathrm{Sr}$ & $2.70 \mathrm{E}+00$ \\
\hline 241-B-202 & ${ }^{137} \mathrm{Cs}$ & $1.26 \mathrm{E}-01$ & GA\&TA & $4.15 \mathrm{E}-01$ & ${ }^{90} \mathrm{Sr}$ & $3.99 \mathrm{E}+00$ \\
\hline 241-BX-107 & ${ }^{137} \mathrm{Cs}$ & $2.21 \mathrm{E}+01$ & GA\&TA & $1.19 \mathrm{E}-01$ & ${ }^{90} \mathrm{Sr}$ & $9.87 \mathrm{E}+00$ \\
\hline 241-BX-109 & ${ }^{137} \mathrm{Cs}$ & $1.32 \mathrm{E}+01$ & GA & $4.99 \mathrm{E}-02$ & ${ }^{89190} \mathrm{Sr}$ & $1.62 \mathrm{E}+02$ \\
\hline $241-\mathrm{BX}-112$ & ${ }^{137} \mathrm{Cs}$ & $5.09 \mathrm{E}+01$ & $\mathrm{GA}$ & $1.90-01$ & ${ }^{90} \mathrm{Sr}$ & $6.17 \mathrm{E}+00$ \\
\hline 241-BY-104 & ${ }^{137} \mathrm{Cs}$ & $1.03 \mathrm{E}+02$ & $\mathrm{GA}$ & $1.13 \mathrm{E}-01$ & ${ }^{89 / 90} \mathrm{Sr}$ & $1.84 \mathrm{E}+02$ \\
\hline 241-BY-105 & ${ }^{137} \mathrm{Cs}$ & $6.55 \mathrm{E}+01$ & $\mathrm{GA}$ & $1.04 \mathrm{E}-01$ & ${ }^{89 / 90} \mathrm{Sr}$ & $1.26 \mathrm{E}+02$ \\
\hline 241-BY-106 & ${ }^{137} \mathrm{Cs}$ & $1.00 \mathrm{E}+02$ & $\mathrm{GA}$ & $2.59 \mathrm{E}-02$ & ${ }^{89 / 90} \mathrm{Sr}$ & $2.67 \mathrm{E}+01$ \\
\hline 241-BY-107 & ${ }^{137} \mathrm{Cs}$ & $1.25 \mathrm{E}+02$ & $\mathrm{GA}$ & $4.68 \mathrm{E}-02$ & ${ }^{89190} \mathrm{Sr}$ & $2.21 \mathrm{E}+01$ \\
\hline $241-\mathrm{BY}-110$ & ${ }^{137} \mathrm{Cs}$ & $9.29 \mathrm{E}+01$ & $\mathrm{GA}$ & $7.24 \mathrm{E}-02$ & ${ }^{89190} \mathrm{Sr}$ & $1.08 \mathrm{E}+02$ \\
\hline 241-C-103 & ${ }^{137} \mathrm{Cs}$ & $1.35 \mathrm{E}+02$ & $\mathrm{GA}$ & $1.14 \mathrm{E}+01$ & ${ }^{8990} \mathrm{Sr}$ & $4 .{ }^{90} \mathrm{E}+03$ \\
\hline $241-C-104$ & ${ }^{137} \mathrm{Cs}$ & $6.15 \mathrm{E}+01$ & $\mathrm{GA}$ & $6.37 \mathrm{E}+00$ & ${ }^{899190} \mathrm{Sr}$ & $3.23 E+02$ \\
\hline $241-C-106$ & ${ }^{137} \mathrm{Cs}$ & $5.53 \mathrm{E}+02$ & $\mathrm{GA}$ & $2.77 \mathrm{E}+00$ & ${ }^{8990} \mathrm{Sr}$ & $5.17 \mathrm{E}+02$ \\
\hline $241-\mathrm{C}-108$ & ${ }^{137} \mathrm{Cs}$ & $1.66 \mathrm{E}+02$ & GA & $7.81 \mathrm{E}-02$ & ${ }^{8990} \mathrm{Sr}$ & $1.95 \mathrm{E}+02$ \\
\hline 241-C-109 & ${ }^{137} \mathrm{Cs}$ & $4.77 \mathrm{E}+02$ & GA\&TA & $2.26 \mathrm{E}-01$ & ${ }^{90} \mathrm{Sr}$ & $9.58 \mathrm{E}+02$ \\
\hline $241-\mathrm{C}-110$ & ${ }^{137} \mathrm{Cs}$ & $1.86 \mathrm{E}+01$ & GA\&TA & $1.34 \mathrm{E}-01$ & ${ }^{90} \mathrm{Sr}$ & $5.04 \mathrm{E}+00$ \\
\hline 241-C-111 & ${ }^{137} \mathrm{Cs}$ & $4.32 \mathrm{E}+01$ & GA & $8.21 \mathrm{E}-01$ & ${ }^{90} \mathrm{Sr}$ & $4.21 \mathrm{E}+03$ \\
\hline $241-C-112$ & ${ }^{137} \mathrm{Cs}$ & $2.04 \mathrm{E}+02$ & GA & $3.35 \mathrm{E}-01$ & ${ }^{90} \mathrm{Sr}$ & $1.29 \mathrm{E}+03$ \\
\hline $241-S-101$ & ${ }^{137} \mathrm{Cs}$ & $1.29 \mathrm{E}+02$ & $\mathrm{GA}$ & $3.49 \mathrm{E}-01$ & ${ }^{89190} \mathrm{Sr}$ & $2.52 \mathrm{E}+02$ \\
\hline $241-S-102$ & ${ }^{137} \mathrm{Cs}$ & $1.17 \mathrm{E}+02$ & $\mathrm{GA}$ & $1.78 \mathrm{E}-01$ & ${ }^{89190} \mathrm{Sr}$ & $2.54 \mathrm{E}+01$ \\
\hline $241-S-104$ & ${ }^{137} \mathrm{Cs}$ & $5.84 \mathrm{E}+01$ & GA\&TA & $4.73 \mathrm{E}-01$ & ${ }^{90} \mathrm{Sr}$ & $3.10 \mathrm{E}+02$ \\
\hline 241-S-106 & ${ }^{137} \mathrm{Cs}$ & $1.01 \mathrm{E}+02$ & GA & $3.09 \mathrm{E}-02$ & ${ }^{89190} \mathrm{Sr}$ & $1.49 \mathrm{E}+01$ \\
\hline 241-S-107 & ${ }^{137} \mathrm{Cs}$ & $8.22 \mathrm{E}+01$ & $\mathrm{GA}$ & $9.24 \mathrm{E}-01$ & ${ }^{89190} \mathrm{Sr}$ & $1.60 \mathrm{E}+02$ \\
\hline 241-S-109 & ${ }^{137} \mathrm{Cs}$ & $7.58 \mathrm{E}+00$ & $\mathrm{GA}$ & $7.74 \mathrm{E}-03$ & ${ }^{89190} \mathrm{Sr}$ & $5.31 \mathrm{E}+00$ \\
\hline $241-S-110$ & ${ }^{137} \mathrm{Cs}$ & $8.78 \mathrm{E}+01$ & $\mathrm{GA}$ & $3.12 \mathrm{E}-01$ & ${ }^{8990} \mathrm{Sr}$ & $1.22 \mathrm{E}+02$ \\
\hline $241-S-111$ & ${ }^{137} \mathrm{Cs}$ & $1.16 \mathrm{E}+02$ & $\mathrm{GA}$ & $3.29 \mathrm{E}-02$ & ${ }^{89190} \mathrm{Sr}$ & $1.34 \mathrm{E}+02$ \\
\hline 241-SX-101 & ${ }^{137} \mathrm{Cs}$ & $1.07 \mathrm{E}+02$ & GA & $4.85 \mathrm{E}-01$ & ${ }^{89190} \mathrm{Sr}$ & $1.20 \mathrm{E}+02$ \\
\hline 241-SX-102 & ${ }^{137} \mathrm{Cs}$ & $1.49 \mathrm{E}+02$ & $\overline{G A}$ & $2.13 \mathrm{E}-01$ & ${ }^{89990} \mathrm{Sr}$ & $1.03 \mathrm{E}+02$ \\
\hline 241-SX-103 & ${ }^{137} \mathrm{Cs}$ & $1.27 \mathrm{E}+02$ & GA & $1.71 \mathrm{E}-01$ & ${ }^{899190} \mathrm{Sr}$ & $1.29 \mathrm{E}+02$ \\
\hline 241-SX-108 & ${ }^{137} \mathrm{Cs}$ & $1.95 \mathrm{E}+02$ & GA & $3.29 \mathrm{E}+00$ & ${ }^{89190} \mathrm{Sr}$ & $3.06 \mathrm{E}+03$ \\
\hline $241-\mathrm{T}-102$ & ${ }^{137} \mathrm{Cs}$ & $2.09 \mathrm{E}+01$ & GA\&TA & $9.86 \mathrm{E}-02$ & ${ }^{90} \mathrm{Sr}$ & $2.38 \mathrm{E}+02$ \\
\hline 241-T-104 & ${ }^{137} \mathrm{Cs}$ & $2.07 \mathrm{E}-01$ & GA\&TA & $1.38 \mathrm{E}-01$ & ${ }^{90} \mathrm{Sr}$ & $2.63 E+00$ \\
\hline 241-T-105 & ${ }^{137} \mathrm{Cs}$ & $4.57 \mathrm{E}+01$ & GA\&TA & $3.61 \mathrm{E}-01$ & ${ }^{90} \mathrm{Sr}$ & $2.80 \mathrm{E}+02$ \\
\hline
\end{tabular}


Table A-1. Mean Analyte Concentration ( $\mu \mathrm{Ci} / \mathrm{g}$ ), SST Solid Samples (2 Sheets)

\begin{tabular}{|l|l|l|l|l|l|c|}
\hline \multicolumn{1}{|c|}{ Tank } & Analyte & \multicolumn{1}{c|}{ Mean } & Analyte & Mean & Analyte & Mean \\
\hline $241-\mathrm{T}-107$ & ${ }^{137} \mathrm{Cs}$ & $2.06 \mathrm{E}+01$ & GA\&TA & $1.87 \mathrm{E}-01$ & ${ }^{90} \mathrm{Sr}$ & $1.20 \mathrm{E}+02$ \\
\hline $241-\mathrm{T}-111$ & ${ }^{137} \mathrm{Cs}$ & $1.34 \mathrm{E}-01$ & GA\&TA & $3.91 \mathrm{E}-01$ & ${ }^{90} \mathrm{Sr}$ & $5.41 \mathrm{E}+00$ \\
\hline $241-\mathrm{T}-201$ & ${ }^{137} \mathrm{Cs}$ & $3.46 \mathrm{E}-02$ & GA & $7.57 \mathrm{E}-01$ & ${ }^{89 / 90} \mathrm{Sr}$ & $8.58 \mathrm{E}-02$ \\
\hline $241-\mathrm{T}-204$ & ${ }^{137} \mathrm{Cs}$ & $7.76 \mathrm{E}-03$ & GA & $1.52 \mathrm{E}-01$ & ${ }^{89190} \mathrm{Sr}$ & $4.60 \mathrm{E}-03$ \\
\hline $241-\mathrm{TX}-118$ & ${ }^{137} \mathrm{Cs}$ & $1.10 \mathrm{E}+01$ & GA & $1.71 \mathrm{E}+01$ & ${ }^{89190} \mathrm{Sr}$ & $2.18 \mathrm{E}+02$ \\
\hline $241-\mathrm{U}-102$ & ${ }^{137} \mathrm{Cs}$ & $1.61 \mathrm{E}+02$ & GA & $1.80 \mathrm{E}-01$ & ${ }^{89190} \mathrm{Sr}$ & $4.06 \mathrm{E}+01$ \\
\hline $241-\mathrm{U}-105$ & ${ }^{137} \mathrm{Cs}$ & $1.53 \mathrm{E}+02$ & GA & $7.39 \mathrm{E}-01$ & ${ }^{89190} \mathrm{Sr}$ & $5.97 \mathrm{E}+01$ \\
\hline $241-\mathrm{U}-106$ & ${ }^{137} \mathrm{Cs}$ & $1.52 \mathrm{E}+02$ & GA & $1.15 \mathrm{E}+00$ & ${ }^{89190} \mathrm{Sr}$ & $7.72 \mathrm{E}+01$ \\
\hline $241-\mathrm{U}-107$ & ${ }^{137} \mathrm{Cs}$ & $8.55 \mathrm{E}+01$ & GA & $2.19 \mathrm{E}-01$ & ${ }^{89190} \mathrm{Sr}$ & $4.34 \mathrm{E}+00$ \\
\hline $241-\mathrm{U}-108$ & ${ }^{137} \mathrm{Cs}$ & $1.44 \mathrm{E}+02$ & GA & $5.25 \mathrm{E}-02$ & ${ }^{89190} \mathrm{Sr}$ & $1.03 \mathrm{E}+01$ \\
\hline $241-\mathrm{U}-109$ & ${ }^{137} \mathrm{Cs}$ & $1.16 \mathrm{E}+02$ & GA & $3.71 \mathrm{E}-02$ & ${ }^{89190} \mathrm{Sr}$ & $8.81 \mathrm{E}+00$ \\
\hline $241-\mathrm{U}-110$ & ${ }^{137} \mathrm{Cs}$ & $2.41 \mathrm{E}+01$ & GA & $7.47 \mathrm{E}-01$ & ${ }^{89190} \mathrm{Sr} \&{ }^{90} \mathrm{Sr}$ & $1.57 \mathrm{E}+02$ \\
\hline
\end{tabular}

Table A-2. Mean Analyte Concentrations ( $\mu \mathrm{Ci} / \mathrm{L})$, SST Liquid Samples

\begin{tabular}{|c|c|c|c|c|c|c|}
\hline Tank & Analyte & Mean & Analyte & Mean & Analyte & Mean \\
\hline $241-A-101$ & ${ }^{137} \mathrm{Cs}$ & $3.53 \mathrm{E}+05$ & GA & $5.68 \mathrm{E}+00$ & ${ }^{89190} \mathrm{Sr}$ & $6.82 \mathrm{E}+01$ \\
\hline 241-BY-105 & ${ }^{137} \mathrm{Cs}$ & $2.10 \mathrm{E}+05$ & $\mathrm{GA}$ & $2.99 \mathrm{E}+01$ & ${ }^{89190} \mathrm{Sr}$ & $1.10 \mathrm{E}+02$ \\
\hline 241-C-106 & ${ }^{137} \mathrm{Cs}$ & $1.25 \mathrm{E}+05$ & GA & $1.02 E+03$ & ${ }^{89 / 10} \mathrm{Sr}$ & $6.10 \mathrm{E}+02$ \\
\hline $241-\mathrm{C}-110$ & ${ }^{137} \mathrm{Cs}$ & $3.88 \mathrm{E}+03$ & $\mathrm{GA}$ & $2.07 \mathrm{E}+00$ & ${ }^{90} \mathrm{Sr}$ & $2.78 \mathrm{E}+01$ \\
\hline $241-S-102$ & ${ }^{137} \mathrm{Cs}$ & $3.24 \mathrm{E}+05$ & GA & $1.21 \mathrm{E}+01$ & ${ }^{89190} \mathrm{Sr}$ & $3.11 \mathrm{E}+02$ \\
\hline $241-S-103$ & ${ }^{1{ }^{137} \mathrm{Cs}}$ & $3.65 \mathrm{E}+05$ & ${ }^{241} \mathrm{Am}$ & $1.19 \mathrm{E}+00$ & ${ }^{879190} \mathrm{Sr}$ & $4.20 \mathrm{E}+02$ \\
\hline $241-S-106$ & ${ }^{137} \mathrm{Cs}$ & $2.67 E+05$ & GA & $2.20 \mathrm{E}+00$ & ${ }^{89190} \mathrm{Sr}$ & $5.67 \mathrm{E}+01$ \\
\hline 241-SX-101 & ${ }^{137} \mathrm{Cs}$ & $4.03 E+05$ & GA & $8.22 \mathrm{E}+02$ & ${ }^{89190} \mathrm{Sr}$ & $8.03 \mathrm{E}+01$ \\
\hline 241-SX-102 & ${ }^{137} \mathrm{Cs}$ & $4.38 E+05$ & GA & $5.87 \mathrm{E}+00$ & ${ }^{89190} \mathrm{Sr}$ & $2.34 \mathrm{E}+01$ \\
\hline 241-SX-103 & ${ }^{137} \mathrm{Cs}$ & $4.40 \mathrm{E}+05$ & $\mathrm{GA}$ & $1.24 \mathrm{E}+01$ & ${ }^{89 / 90} \mathrm{Sr}$ & $1.15 \mathrm{E}+02$ \\
\hline 241-SX-104 & ${ }^{137} \mathrm{Cs}$ & $2.83 E+05$ & $2{ }^{241} \mathrm{Am}$ & $2.62 \mathrm{E}-02$ & ${ }^{89190} \mathrm{Sr}$ & $6.33 \mathrm{E}+01$ \\
\hline 241-SX-105 & ${ }^{137} \mathrm{Cs}$ & $3.84 \mathrm{E}+05$ & $\mathrm{GA}$ & $7.32 \mathrm{E}+00$ & ${ }^{89190} \mathrm{Sr}$ & $1.60 \mathrm{E}+02$ \\
\hline 241-SX-106 & ${ }^{137} \mathrm{Cs}$ & $3.77 \mathrm{E}+05$ & $\overline{\mathrm{GA}}$ & $4.11 E+00$ & ${ }^{89190} \mathrm{Sr}$ & $3.40 \mathrm{E}+02$ \\
\hline $241-\mathrm{T}-107$ & ${ }^{137} \mathrm{Cs}$ & $8.43 \mathrm{E}+03$ & GA & $6.01 \mathrm{E}+00$ & ${ }^{90} \mathrm{Sr}$ & $5.94 \mathrm{E}+01$ \\
\hline $241-T-110$ & ${ }^{137} \mathrm{Cs}$ & $3.43 \mathrm{E}+00$ & GA & $1.02 \mathrm{E}-01$ & ${ }^{90} \mathrm{Sr}$ & $5.30 \mathrm{E}-01$ \\
\hline $241-\mathrm{U}-102$ & ${ }^{137} \mathrm{Cs}$ & $3.40 \mathrm{E}+05$ & GA & $3.12 \mathrm{E}+01$ & ${ }^{89190} \mathrm{Sr}$ & $8.83 E+03$ \\
\hline 241-U-103 & ${ }^{137} \mathrm{Cs}$ & $3.77 \mathrm{E}+05$ & GA & $3.01 \mathrm{E}+01$ & ${ }^{89 / 10} \mathrm{Sr}$ & $1.05 \mathrm{E}+04$ \\
\hline 241-U-107 & ${ }^{137} \mathrm{Cs}$ & $3.52 \mathrm{E}+05$ & GA & $1.12 \mathrm{E}+01$ & ${ }^{89 / 90} \mathrm{Sr}$ & $3.61 \mathrm{E}+02$ \\
\hline $241-\mathrm{U}-108$ & ${ }^{137} \mathrm{Cs}$ & $4.16 \mathrm{E}+05$ & $\mathrm{GA}$ & $8.88 \mathrm{E}+00$ & ${ }^{89190} \mathrm{Sr}$ & $3.45 \mathrm{E}+02$ \\
\hline 241-U-109 & ${ }^{137} \mathrm{Cs}$ & $3.66 \mathrm{E}+05$ & GA & $1.07 \mathrm{E}+00$ & ${ }^{89190} \mathrm{Sr}$ & $9.31 E+02$ \\
\hline
\end{tabular}


Table A-3. Mean Analyte Concentrations ( $\mu \mathrm{Ci} / \mathrm{g}$ ), DST Solid Samples

\begin{tabular}{|c|c|c|c|c|c|c|}
\hline Tank & Analyte & Mean & Analyte & Mean & Analyte & Mean \\
\hline $241-\mathrm{AN}-102$ & ${ }^{137} \mathrm{Cs}$ & $2.39 \mathrm{E}+02$ & GA & $5.52 \mathrm{E}-01$ & ${ }^{89190} \mathrm{Sr}$ & $1.17 \mathrm{E}+02$ \\
\hline $241-\mathrm{AN}-103$ & ${ }^{137} \mathrm{Cs}$ & $2.51 \mathrm{E}+02$ & GA & $1.72 \mathrm{E}-02$ & ${ }^{8990} \mathrm{Sr}$ & $2.66 \mathrm{E}+00$ \\
\hline $241-\mathrm{AN}-104$ & ${ }^{137} \mathrm{Cs}$ & $3.46 \mathrm{E}+02$ & GA & $4.07 \mathrm{E}-02$ & ${ }^{8990} \mathrm{Sr}$ & $3.36 \mathrm{E}+01$ \\
\hline $241-\mathrm{AN}-105$ & ${ }^{137} \mathrm{Cs}$ & $2.67 \mathrm{E}+02$ & GA & $2.78 \mathrm{E}-02$ & ${ }^{89900} \mathrm{Sr}$ & $1.87 \mathrm{E}+01$ \\
\hline $241-\mathrm{AN}-107$ & ${ }^{137} \mathrm{Cs}$ & $1.74 \mathrm{E}+02$ & GA & $1.00 \mathrm{E}+00$ & ${ }^{89100} \mathrm{Sr}$ & $2.53 \mathrm{E}+02$ \\
\hline $241-\mathrm{AW}-101$ & ${ }^{137} \mathrm{Cs}$ & $2.30 \mathrm{E}+02$ & GA & $1.34 \mathrm{E}-01$ & ${ }^{89900} \mathrm{Sr}$ & $8.28 \mathrm{E}+01$ \\
\hline $241-\mathrm{AW}-102$ & ${ }^{137} \mathrm{Cs}$ & $8.64 \mathrm{E}+01$ & GA & $2.40 \mathrm{E}+00$ & ${ }^{89190} \mathrm{Sr}$ & $6.64 \mathrm{E}+02$ \\
\hline $241-\mathrm{AW}-105$ & ${ }^{137} \mathrm{Cs}$ & $3.82 \mathrm{E}+01$ & GA & $1.75 \mathrm{E}+00$ & ${ }^{8990} \mathrm{Sr} \&{ }^{90} \mathrm{Sr}$ & $6.22 \mathrm{E}+01$ \\
\hline $241-\mathrm{AW}-106$ & ${ }^{137} \mathrm{Cs}$ & $1.15 \mathrm{E}+02$ & GA & $2.22 \mathrm{E}-01$ & ${ }^{89190} \mathrm{Sr}$ & $2.26 \mathrm{E}+01$ \\
\hline $241-\mathrm{AY}-101$ & ${ }^{137} \mathrm{Cs}$ & $8.56 \mathrm{E}+01$ & GA & $4.39 \mathrm{E}+00$ & ${ }^{89190} \mathrm{Sr}$ & $4.61 \mathrm{E}+03$ \\
\hline $241-\mathrm{AY}-102$ & ${ }^{137} \mathrm{Cs}$ & $2.83 \mathrm{E}+02$ & ${ }^{241} \mathrm{Am}$ & $2.24 \mathrm{E}+01$ & ${ }^{89190} \mathrm{Sr}$ & $7.67 \mathrm{E}+04$ \\
\hline $241-\mathrm{SY}-101$ & ${ }^{137} \mathrm{Cs}$ & $3.50 \mathrm{E}+02$ & GA & $8.17 \mathrm{E}-01$ & ${ }^{90} \mathrm{Sr}$ & $2.97 \mathrm{E}+01$ \\
\hline $241-\mathrm{SY}-103$ & ${ }^{137} \mathrm{Cs}$ & $2.26 \mathrm{E}+02$ & GA & $8.93 \mathrm{E}-01$ & ${ }^{89190} \mathrm{Sr}$ & $9.64 \mathrm{E}+00$ \\
\hline
\end{tabular}

Table A-4. Mean Analyte Concentrations ( $\mu \mathrm{Ci} / \mathrm{L}$ ), DST Liquid Samples (2 Sheets)

\begin{tabular}{|c|c|c|c|c|c|c|}
\hline Tank & Analyte & Mean & Analyte & Mean & Analyte & Mean \\
\hline 241-AN-101 & ${ }^{137} \mathrm{Cs}$ & $1.01 \mathrm{E}+05$ & ${ }^{241} \mathrm{Am}$ & $3.86 \mathrm{E}-02$ & ${ }^{89190} \mathrm{Sr}$ & $2.09 \mathrm{E}+02$ \\
\hline $241-\mathrm{AN}-102$ & ${ }^{137} \mathrm{Cs}$ & $3.66 \mathrm{E}+05$ & $\mathrm{GA}$ & $1.76 \mathrm{E}+02$ & ${ }^{89990} \mathrm{Sr}$ & $8.47 \mathrm{E}+04$ \\
\hline $241-\mathrm{AN}-103$ & ${ }^{137} \mathrm{Cs}$ & $7.86 \mathrm{E}+05$ & $\mathrm{GA}$ & $5.77 \mathrm{E}+01$ & ${ }^{89 / 90} \mathrm{Sr}$ & $2.08 \mathrm{E}+01$ \\
\hline 241-AN-104 & ${ }^{137} \mathrm{Cs}$ & $6.54 \mathrm{E}+05$ & GA & $1.23 \mathrm{E}+01$ & ${ }^{89190} \mathrm{Sr}$ & $1.31 \mathrm{E}+02$ \\
\hline $241-\mathrm{AN}-105$ & ${ }^{137} \mathrm{Cs}$ & $4.02 E+05$ & $\mathrm{GA}$ & $2.84 \mathrm{E}+01$ & ${ }^{89 / 90} \mathrm{Sr}$ & $4.14 E+01$ \\
\hline 241-AN-1 & ${ }^{137} \mathrm{Cs}$ & $3.63 \mathrm{E} t$ & $\mathrm{GA}$ & $8.17 \mathrm{E}+02$ & ${ }^{89190} \mathrm{Sr}$ & $1.01 \mathrm{E}+05$ \\
\hline $241-A$ & ${ }^{137} \mathrm{Cs}$ & $1.61 \mathrm{~F}$ & $\mathrm{GA}$ & $5.95 \mathrm{E}-03$ & ${ }^{89 / 90} \mathrm{Sr} \&{ }^{90} \mathrm{Sr}$ & $1.33 \mathrm{E}+02$ \\
\hline $241-A$ & ${ }^{137} \mathrm{Cs}$ & 2.25 & ${ }^{241} \mathrm{Am}$ & $4.34 \mathrm{E}-01$ & ${ }^{90} \mathrm{Sr}$ & $1.45 \mathrm{E}+03$ \\
\hline $241-\mathrm{AP}$ & ${ }^{137} \mathrm{Cs}$ & $6.53 \mathrm{E}$ & ${ }^{239 / 240} \mathrm{Pu}$ & $4.31 \mathrm{E}-03$ & ${ }^{89190} \mathrm{Sr} \&{ }^{90} \mathrm{Sr}$ & $7.04 \mathrm{E}+00$ \\
\hline $241-\mathrm{AP}$ & ${ }^{137} \mathrm{Cs}$ & $4.97 \mathrm{E}$ & GA & $3.28 \mathrm{E}-01$ & ${ }^{89 / 90} \mathrm{Sr}$ & $8.28 \mathrm{E}+01$ \\
\hline$\frac{241-2}{241-}$ & ${ }^{137} \mathrm{Cs}$ & $2.10 \mathrm{E}$ & GA & $1.01 \mathrm{E}+01$ & ${ }^{89 / 10} \mathrm{Sr} \&{ }^{90} \mathrm{Sr}$ & $2.06 \mathrm{E}+02$ \\
\hline $241-$ & ${ }^{137} \mathrm{Cs}$ & $3.98 \mathrm{E}$ & ${ }^{241} \mathrm{Am}$ & 3.65E-01 & ${ }^{89 / 90} \mathrm{Sr} \&{ }^{90} \mathrm{Sr}$ & $1.54 \mathrm{E}+02$ \\
\hline $241-\mathrm{Al}$ & ${ }^{137} \mathrm{Cs}$ & $1.20 \mathrm{E}+04$ & ${ }^{239 / 240} \mathrm{Pu}$ & $9.29 \mathrm{E}-02$ & ${ }^{80190} \mathrm{Sr} \&{ }^{90} \mathrm{Sr}$ & $4.63 \mathrm{E}+01$ \\
\hline $241-t$ & ${ }^{137} \mathrm{Cs}$ & $5.59 \mathrm{E}+04$ & ${ }^{241} \mathrm{Am}$ & $1.99 \mathrm{E}-01$ & ${ }^{89 / 90} \mathrm{Sr}$ & $1.95 \mathrm{E}+02$ \\
\hline $241-$ & ${ }^{137} \mathrm{Cs}$ & $3.88 \mathrm{E}+05$ & $\overline{\mathrm{GA}}$ & $7.85 \mathrm{E}+00$ & ${ }^{8990} \mathrm{Sr}$ & $2.92 \mathrm{E}+02$ \\
\hline $241-$ & ${ }^{137} \mathrm{Cs}$ & $3.53 E+04$ & $\mathrm{GA}$ & $1.68 E+00$ & ${ }^{89 / 90} \mathrm{Sr} \& \alpha^{90} \mathrm{Sr}$ & $2.09 E+02$ \\
\hline $241-A$ & ${ }^{137} \mathrm{Cs}$ & $2.06 \mathrm{E}+04$ & $239 / 240 \mathrm{Pu}$ & $9.86 \mathrm{E}-03$ & ${ }^{90} \mathrm{Sr}$ & $2.20 \mathrm{E}-01$ \\
\hline 241-AW-104 & ${ }^{137} \mathrm{Cs}$ & $4.54 \mathrm{E}+03$ & $\mathrm{GA}$ & $4.45 \mathrm{E}+00$ & ${ }^{90} \mathrm{Sr}$ & $7.79 \mathrm{E}+00$ \\
\hline 241-AW-105 & ${ }^{137} \mathrm{Cs}$ & $1.41 \mathrm{E}+04$ & $\mathrm{GA}$ & $1.83 \mathrm{E}+00$ & ${ }^{89190} \mathrm{Sr} \&{ }^{90} \mathrm{Sr}$ & $6.51 \mathrm{E}+01$ \\
\hline 241-AW-106 & ${ }^{137} \mathrm{Cs}$ & $1.86 E+05$ & GA & $2.87 \mathrm{E}+01$ & ${ }^{89190} \mathrm{Sr} \&{ }^{90} \mathrm{Sr}$ & $3.82 E+02$ \\
\hline 241-AY-101 & ${ }^{137} \mathrm{Cs}$ & $8.81 \mathrm{E}+04$ & GA & $6.36 \mathrm{E}+01$ & ${ }^{89190} \mathrm{Sr}$ & $1.89 \mathrm{E}+03$ \\
\hline
\end{tabular}


Table A-4. Mean Analyte Concentrations ( $\mu \mathrm{Ci} / \mathrm{L})$, DST Liquid Samples (2 Sheets)

\begin{tabular}{|c|l|c|l|l|l|c|}
\hline Tank & Analyte & \multicolumn{1}{|c|}{ Mean } & Analyte & \multicolumn{1}{c|}{ Mean } & \multicolumn{1}{c|}{ Analyte } & Mean \\
\hline $241-\mathrm{AY}-102$ & ${ }^{137} \mathrm{Cs}$ & $3.59 \mathrm{E}+03$ & ${ }^{241} \mathrm{Am}$ & $5.17 \mathrm{E}-01$ & ${ }^{89190} \mathrm{Sr} \&{ }^{90} \mathrm{Sr}$ & $1.19 \mathrm{E}+03$ \\
\hline $241-\mathrm{SY}-101$ & ${ }^{137} \mathrm{Cs}$ & $9.06 \mathrm{E}+05$ & GA & $3.72 \mathrm{E}+01$ & ${ }^{90} \mathrm{Sr}$ & $1.53 \mathrm{E}+03$ \\
\hline $241-\mathrm{SY}-102$ & ${ }^{137} \mathrm{Cs}$ & $3.05 \mathrm{E}+04$ & GA & $2.26 \mathrm{E}+01$ & ${ }^{89 / 90} \mathrm{Sr}$ & $2.47 \mathrm{E}+02$ \\
\hline $241-\mathrm{SY}-103$ & ${ }^{137} \mathrm{Cs}$ & $3.99 \mathrm{E}+05$ & ${ }^{241} \mathrm{Am}$ & $1.87 \mathrm{E}+00$ & ${ }^{89 / 90} \mathrm{Sr}$ & $2.69 \mathrm{E}+03$ \\
\hline
\end{tabular}

Table A-5. Sv/L by Analyte and ULD, SST Solid Samples (2 Sheets)

\begin{tabular}{|l|l|l|l|l|}
\hline \multicolumn{1}{|c|}{ Tank } & \multicolumn{1}{|c|}{${ }^{137} \mathrm{Cs}$} & \multicolumn{1}{c|}{ Alpha } & ${ }^{90} \mathrm{Sr}+{ }^{90} \mathrm{Y}$ & ULD \\
\hline $241-\mathrm{A}-101$ & $1.04 \mathrm{E}+02$ & $4.37 \mathrm{E}+02$ & $6.15 \mathrm{E}+01$ & $6.02 \mathrm{E}+02$ \\
\hline $241-\mathrm{AX}-101$ & $1.02 \mathrm{E}+02$ & $3.67 \mathrm{E}+02$ & $7.22 \mathrm{E}+01$ & $5.41 \mathrm{E}+02$ \\
\hline $241-\mathrm{AX}-104$ & $3.10 \mathrm{E}+02$ & $9.83 \mathrm{E}+04$ & $7.44 \mathrm{E}+04$ & $1.73 \mathrm{E}+05$ \\
\hline $241-\mathrm{B}-106$ & $1.04 \mathrm{E}+01$ & $3.49 \mathrm{E}+02$ & $2.85 \mathrm{E}+02$ & $6.44 \mathrm{E}+02$ \\
\hline $241-\mathrm{B}-108$ & $8.80 \mathrm{E}+00$ & $5.61 \mathrm{E}+01$ & $1.14 \mathrm{E}+01$ & $7.63 \mathrm{E}+01$ \\
\hline $241-\mathrm{B}-111$ & $7.61 \mathrm{E}+01$ & $8.77 \mathrm{E}+02$ & $9.83 \mathrm{E}+02$ & $2.07 \mathrm{E}+03$ \\
\hline $241-\mathrm{B}-201$ & $2.35 \mathrm{E}+00$ & $7.55 \mathrm{E}+03$ & $1.07 \mathrm{E}+01$ & $4.51 \mathrm{E}+03$ \\
\hline $241-\mathrm{B}-202$ & $6.43 \mathrm{E}-02$ & $2.95 \mathrm{E}+03$ & $1.58 \mathrm{E}+01$ & $2.89 \mathrm{E}+03$ \\
\hline $241-\mathrm{BX}-107$ & $1.13 \mathrm{E}+01$ & $8.47 \mathrm{E}+02$ & $3.91 \mathrm{E}+01$ & $9.26 \mathrm{E}+02$ \\
\hline $241-\mathrm{BX}-109$ & $6.74 \mathrm{E}+00$ & $3.54 \mathrm{E}+02$ & $6.43 \mathrm{E}+02$ & $1.00 \mathrm{E}+03$ \\
\hline $241-\mathrm{BX}-112$ & $2.60 \mathrm{E}+01$ & $1.35 \mathrm{E}+03$ & $2.45 \mathrm{E}+01$ & $1.40 \mathrm{E}+03$ \\
\hline $241-\mathrm{BY}-104$ & $5.27 \mathrm{E}+01$ & $8.00 \mathrm{E}+02$ & $7.28 \mathrm{E}+02$ & $1.58 \mathrm{E}+03$ \\
\hline $241-\mathrm{BY}-105$ & $3.35 \mathrm{E}+01$ & $7.39 \mathrm{E}+02$ & $4.99 \mathrm{E}+02$ & $1.27 \mathrm{E}+03$ \\
\hline $241-\mathrm{BY}-106$ & $5.12 \mathrm{E}+01$ & $1.84 \mathrm{E}+02$ & $1.06 \mathrm{E}+02$ & $3.41 \mathrm{E}+02$ \\
\hline $241-\mathrm{BY}-107$ & $6.37 \mathrm{E}+01$ & $3.33 \mathrm{E}+02$ & $8.77 \mathrm{E}+01$ & $4.84 \mathrm{E}+02$ \\
\hline $241-\mathrm{BY}-110$ & $4.75 \mathrm{E}+01$ & $5.15 \mathrm{E}+02$ & $4.27 \mathrm{E}+02$ & $8.57 \mathrm{E}+02$ \\
\hline $241-\mathrm{C}-103$ & $6.91 \mathrm{E}+01$ & $8.08 \mathrm{E}+04$ & $1.94 \mathrm{E}+04$ & $1.00 \mathrm{E}+05$ \\
\hline $241-\mathrm{C}-104$ & $3.14 \mathrm{E}+01$ & $4.53 \mathrm{E}+04$ & $1.28 \mathrm{E}+03$ & $4.66 \mathrm{E}+04$ \\
\hline $241-\mathrm{C}-106$ & $2.83 \mathrm{E}+02$ & $1.97 \mathrm{E}+04$ & $2.05 \mathrm{E}+03$ & $2.20 \mathrm{E}+04$ \\
\hline $241-\mathrm{C}-108$ & $8.50 \mathrm{E}+01$ & $5.54 \mathrm{E}+02$ & $7.74 \mathrm{E}+02$ & $2.65 \mathrm{E}+03$ \\
\hline $241-\mathrm{C}-109$ & $2.44 \mathrm{E}+02$ & $1.60 \mathrm{E}+03$ & $3.80 \mathrm{E}+03$ & $5.18 \mathrm{E}+03$ \\
\hline $241-\mathrm{C}-110$ & $9.51 \mathrm{E}+00$ & $9.50 \mathrm{E}+02$ & $2.00 \mathrm{E}+01$ & $9.16 \mathrm{E}+02$ \\
\hline $241-\mathrm{C}-111$ & $2.21 \mathrm{E}+01$ & $5.83 \mathrm{E}+03$ & $1.67 \mathrm{E}+04$ & $2.26 \mathrm{E}+04$ \\
\hline $241-\mathrm{C}-112$ & $1.04 \mathrm{E}+02$ & $2.38 \mathrm{E}+03$ & $5.12 \mathrm{E}+03$ & $7.60 \mathrm{E}+03$ \\
\hline $241-\mathrm{S}-101$ & $6.58 \mathrm{E}+01$ & $2.48 \mathrm{E}+03$ & $9.99 \mathrm{E}+02$ & $3.54 \mathrm{E}+03$ \\
\hline $241-\mathrm{S}-102$ & $5.97 \mathrm{E}+01$ & $1.27 \mathrm{E}+03$ & $1.01 \mathrm{E}+02$ & $1.67 \mathrm{E}+03$ \\
\hline $241-\mathrm{S}-104$ & $2.98 \mathrm{E}+01$ & $3.36 \mathrm{E}+03$ & $1.23 \mathrm{E}+03$ & $5.18 \mathrm{E}+03$ \\
\hline $241-\mathrm{S}-106$ & $5.17 \mathrm{E}+01$ & $2.19 \mathrm{E}+02$ & $5.92 \mathrm{E}+01$ & $3.30 \mathrm{E}+02$ \\
\hline $241-\mathrm{S}-107$ & $4.20 \mathrm{E}+01$ & $6.57 \mathrm{E}+03$ & $6.36 \mathrm{E}+02$ & $7.25 \mathrm{E}+03$ \\
\hline $241-\mathrm{S}-109$ & $3.87 \mathrm{E}+00$ & $5.50 \mathrm{E}+01$ & $2.10 \mathrm{E}+01$ & $7.99 \mathrm{E}+01$ \\
\hline & & & & \\
\hline
\end{tabular}


Table A-5. Sv/L by Analyte and ULD, SST Solid Samples (2 Sheets)

\begin{tabular}{|l|l|l|l|r|}
\hline \multicolumn{1}{|c|}{ Tank } & \multicolumn{1}{c|}{${ }^{137} \mathrm{Cs}$} & \multicolumn{1}{c|}{ Alpha } & ${ }^{90} \mathrm{Sr}+{ }^{90} \mathrm{Y}$ & ULD \\
\hline $241-\mathrm{S}-110$ & $4.49 \mathrm{E}+01$ & $2.22 \mathrm{E}+03$ & $4.85 \mathrm{E}+02$ & $2.75 \mathrm{E}+03$ \\
\hline $241-\mathrm{S}-111$ & $5.94 \mathrm{E}+01$ & $2.33 \mathrm{E}+02$ & $5.31 \mathrm{E}+02$ & $8.24 \mathrm{E}+02$ \\
\hline $241-\mathrm{SX}-101$ & $5.47 \mathrm{E}+01$ & $3.45 \mathrm{E}+03$ & $4.78 \mathrm{E}+02$ & $3.98 \mathrm{E}+03$ \\
\hline $241-\mathrm{SX}-102$ & $7.62 \mathrm{E}+01$ & $1.51 \mathrm{E}+03$ & $4.08 \mathrm{E}+02$ & $2.00 \mathrm{E}+03$ \\
\hline $241-\mathrm{SX}-103$ & $6.51 \mathrm{E}+01$ & $1.22 \mathrm{E}+03$ & $5.10 \mathrm{E}+02$ & $1.79 \mathrm{E}+03$ \\
\hline $241-\mathrm{SX}-108$ & $9.96 \mathrm{E}+01$ & $2.34 \mathrm{E}+04$ & $1.21 \mathrm{E}+04$ & $3.56 \mathrm{E}+04$ \\
\hline $241-\mathrm{T}-102$ & $1.07 \mathrm{E}+01$ & $7.01 \mathrm{E}+02$ & $9.44 \mathrm{E}+02$ & $3.14 \mathrm{E}+03$ \\
\hline $241-\mathrm{T}-104$ & $1.06 \mathrm{E}-01$ & $9.81 \mathrm{E}+02$ & $1.04 \mathrm{E}+01$ & $1.01 \mathrm{E}+03$ \\
\hline $241-\mathrm{T}-105$ & $2.33 \mathrm{E}+01$ & $2.56 \mathrm{E}+03$ & $1.11 \mathrm{E}+03$ & $3.47 \mathrm{E}+03$ \\
\hline $241-\mathrm{T}-107$ & $1.05 \mathrm{E}+01$ & $1.33 \mathrm{E}+03$ & $4.75 \mathrm{E}+02$ & $1.74 \mathrm{E}+03$ \\
\hline $241-\mathrm{T}-111$ & $6.84 \mathrm{E}-02$ & $2.78 \mathrm{E}+03$ & $2.15 \mathrm{E}+01$ & $2.66 \mathrm{E}+03$ \\
\hline $241-\mathrm{T}-201$ & $1.77 \mathrm{E}-02$ & $5.37 \mathrm{E}+03$ & $3.40 \mathrm{E}-01$ & $5.37 \mathrm{E}+03$ \\
\hline $241-\mathrm{T}-204$ & $3.96 \mathrm{E}-03$ & $1.08 \mathrm{E}+03$ & $1.82 \mathrm{E}-02$ & $1.08 \mathrm{E}+03$ \\
\hline $241-\mathrm{TX}-118$ & $5.63 \mathrm{E}+00$ & $1.22 \mathrm{E}+05$ & $8.63 \mathrm{E}+02$ & $1.22 \mathrm{E}+05$ \\
\hline $241-\mathrm{U}-102$ & $8.20 \mathrm{E}+01$ & $1.28 \mathrm{E}+03$ & $1.61 \mathrm{E}+02$ & $1.52 \mathrm{E}+03$ \\
\hline $241-\mathrm{U}-105$ & $7.80 \mathrm{E}+01$ & $5.25 \mathrm{E}+03$ & $2.37 \mathrm{E}+02$ & $5.56 \mathrm{E}+03$ \\
\hline $241-\mathrm{U}-106$ & $7.76 \mathrm{E}+01$ & $8.15 \mathrm{E}+03$ & $3.06 \mathrm{E}+02$ & $8.54 \mathrm{E}+03$ \\
\hline $241-\mathrm{U}-107$ & $4.37 \mathrm{E}+01$ & $1.55 \mathrm{E}+03$ & $1.72 \mathrm{E}+01$ & $1.61 \mathrm{E}+03$ \\
\hline $241-\mathrm{U}-108$ & $7.34 \mathrm{E}+01$ & $3.73 \mathrm{E}+02$ & $4.10 \mathrm{E}+01$ & $4.88 \mathrm{E}+02$ \\
\hline $241-\mathrm{U}-109$ & $5.92 \mathrm{E}+01$ & $2.64 \mathrm{E}+02$ & $3.49 \mathrm{E}+01$ & $3.58 \mathrm{E}+02$ \\
\hline $241-\mathrm{U}-110$ & $1.23 \mathrm{E}+01$ & $5.31 \mathrm{E}+03$ & $6.23 \mathrm{E}+02$ & $5.94 \mathrm{E}+03$ \\
\hline
\end{tabular}


Table A-6. Sv/L by Analyte and ULD, SST Liquid Samples

\begin{tabular}{|l|l|l|l|l|}
\hline \multicolumn{1}{|c|}{ Tank } & \multicolumn{1}{c|}{${ }^{137} \mathrm{Cs}$} & \multicolumn{1}{c|}{ Alpha } & \multicolumn{1}{c|}{${ }^{90} \mathrm{Sr}+{ }^{90} \mathrm{Y}$} & \multicolumn{1}{c|}{ ULD } \\
\hline $241-\mathrm{A}-101$ & $1.13 \mathrm{E}+02$ & $2.52 \mathrm{E}+01$ & $1.69 \mathrm{E}-01$ & $1.38 \mathrm{E}+02$ \\
\hline $241-\mathrm{BY}-105$ & $6.72 \mathrm{E}+01$ & $1.33 \mathrm{E}+02$ & $2.72 \mathrm{E}-01$ & $2.00 \mathrm{E}+02$ \\
\hline $241-\mathrm{C}-106$ & $3.98 \mathrm{E}+01$ & $4.55 \mathrm{E}+03$ & $1.51 \mathrm{E}+00$ & $4.59 \mathrm{E}+03$ \\
\hline $241-\mathrm{C}-110$ & $1.24 \mathrm{E}+00$ & $9.19 \mathrm{E}+00$ & $6.88 \mathrm{E}-02$ & $1.05 \mathrm{E}+01$ \\
\hline $241-\mathrm{S}-102$ & $1.04 \mathrm{E}+02$ & $5.37 \mathrm{E}+01$ & $7.70 \mathrm{E}-01$ & $1.58 \mathrm{E}+02$ \\
\hline $241-\mathrm{S}-103$ & $1.17 \mathrm{E}+02$ & $5.28 \mathrm{E}+00$ & $1.04 \mathrm{E}+00$ & $1.23 \mathrm{E}+02$ \\
\hline $241-\mathrm{S}-106$ & $8.52 \mathrm{E}+01$ & $9.75 \mathrm{E}+00$ & $1.41 \mathrm{E}-01$ & $9.51 \mathrm{E}+01$ \\
\hline $241-\mathrm{SX}-101$ & $1.29 \mathrm{E}+02$ & $3.65 \mathrm{E}+03$ & $1.99 \mathrm{E}-01$ & $3.78 \mathrm{E}+03$ \\
\hline $241-\mathrm{SX}-102$ & $1.40 \mathrm{E}+02$ & $2.60 \mathrm{E}+01$ & $5.80 \mathrm{E}-02$ & $1.66 \mathrm{E}+02$ \\
\hline $241-\mathrm{SX}-103$ & $1.40 \mathrm{E}+02$ & $5.49 \mathrm{E}+01$ & $2.85 \mathrm{E}-01$ & $1.95 \mathrm{E}+02$ \\
\hline $241-\mathrm{SX}-104$ & $9.04 \mathrm{E}+01$ & $1.16 \mathrm{E}-01$ & $1.57 \mathrm{E}-01$ & $9.06 \mathrm{E}+01$ \\
\hline $241-\mathrm{SX}-105$ & $1.23 \mathrm{E}+02$ & $3.25 \mathrm{E}+01$ & $3.96 \mathrm{E}-01$ & $1.55 \mathrm{E}+02$ \\
\hline $241-\mathrm{SX}-106$ & $1.20 \mathrm{E}+02$ & $1.82 \mathrm{E}+01$ & $8.43 \mathrm{E}-01$ & $1.40 \mathrm{E}+02$ \\
\hline $241-\mathrm{T}-107$ & $2.69 \mathrm{E}+00$ & $2.67 \mathrm{E}+01$ & $1.47 \mathrm{E}-01$ & $2.95 \mathrm{E}+01$ \\
\hline $241-\mathrm{T}-110$ & $1.10 \mathrm{E}-03$ & $4.53 \mathrm{E}-01$ & $1.31 \mathrm{E}-03$ & $4.55 \mathrm{E}-01$ \\
\hline $241-\mathrm{U}-102$ & $1.08 \mathrm{E}+02$ & $1.39 \mathrm{E}+02$ & $2.19 \mathrm{E}+01$ & $2.69 \mathrm{E}+02$ \\
\hline $241-\mathrm{U}-103$ & $1.20 \mathrm{E}+02$ & $1.34 \mathrm{E}+02$ & $2.60 \mathrm{E}+01$ & $2.80 \mathrm{E}+02$ \\
\hline $241-\mathrm{U}-107$ & $1.12 \mathrm{E}+02$ & $4.98 \mathrm{E}+01$ & $8.94 \mathrm{E}-01$ & $1.63 \mathrm{E}+02$ \\
\hline $241-\mathrm{U}-108$ & $1.33 \mathrm{E}+02$ & $3.94 \mathrm{E}+01$ & $8.54 \mathrm{E}-01$ & $1.73 \mathrm{E}+02$ \\
\hline $241-\mathrm{U}-109$ & $1.17 \mathrm{E}+02$ & $4.75 \mathrm{E}+00$ & $2.31 \mathrm{E}+00$ & $1.24 \mathrm{E}+02$ \\
\hline
\end{tabular}

Table A-7. Sv/L by Analyte and ULD, DST Solid Samples

\begin{tabular}{|l|l|l|l|l|}
\hline \multicolumn{1}{c|}{ Tank } & \multicolumn{1}{c|}{${ }^{137} \mathrm{Cs}$} & \multicolumn{1}{c|}{ Alpha } & ${ }^{90} \mathrm{Sr}+{ }^{90} \mathrm{Y}$ & ULD \\
\hline $241-\mathrm{AN}-102$ & $1.22 \mathrm{E}+02$ & $3.92 \mathrm{E}+03$ & $4.63 \mathrm{E}+02$ & $4.51 \mathrm{E}+03$ \\
\hline $241-\mathrm{AN}-103$ & $1.28 \mathrm{E}+02$ & $1.22 \mathrm{E}+02$ & $1.05 \mathrm{E}+01$ & $2.61 \mathrm{E}+02$ \\
\hline $241-\mathrm{AN}-104$ & $1.77 \mathrm{E}+02$ & $2.89 \mathrm{E}+02$ & $1.33 \mathrm{E}+02$ & $5.99 \mathrm{E}+02$ \\
\hline $241-\mathrm{AN}-105$ & $1.36 \mathrm{E}+02$ & $1.98 \mathrm{E}+02$ & $7.43 \mathrm{E}+01$ & $4.08 \mathrm{E}+02$ \\
\hline $241-\mathrm{AN}-107$ & $8.88 \mathrm{E}+01$ & $7.13 \mathrm{E}+03$ & $1.00 \mathrm{E}+03$ & $8.22 \mathrm{E}+03$ \\
\hline $241-\mathrm{AW}-101$ & $1.17 \mathrm{E}+02$ & $9.54 \mathrm{E}+02$ & $3.28 \mathrm{E}+02$ & $1.40 \mathrm{E}+03$ \\
\hline $241-\mathrm{AW}-102$ & $4.41 \mathrm{E}+01$ & $1.71 \mathrm{E}+04$ & $2.63 \mathrm{E}+03$ & $1.97 \mathrm{E}+04$ \\
\hline $241-\mathrm{AW}-105$ & $1.95 \mathrm{E}+01$ & $1.25 \mathrm{E}+04$ & $2.47 \mathrm{E}+02$ & $1.27 \mathrm{E}+04$ \\
\hline $241-\mathrm{AW}-106$ & $5.85 \mathrm{E}+01$ & $1.57 \mathrm{E}+03$ & $8.96 \mathrm{E}+01$ & $1.72 \mathrm{E}+03$ \\
\hline $241-\mathrm{AY}-101$ & $4.37 \mathrm{E}+01$ & $3.12 \mathrm{E}+04$ & $1.83 \mathrm{E}+04$ & $4.95 \mathrm{E}+04$ \\
\hline $241-\mathrm{AY}-102$ & $1.45 \mathrm{E}+02$ & $1.59 \mathrm{E}+05$ & $3.04 \mathrm{E}+05$ & $4.63 \mathrm{E}+05$ \\
\hline $241-\mathrm{SY}-101$ & $1.79 \mathrm{E}+02$ & $5.80 \mathrm{E}+03$ & $1.18 \mathrm{E}+02$ & $6.10 \mathrm{E}+03$ \\
\hline $241-\mathrm{SY}-103$ & $1.16 \mathrm{E}+02$ & $6.35 \mathrm{E}+03$ & $3.82 \mathrm{E}+01$ & $5.34 \mathrm{E}+03$ \\
\hline
\end{tabular}


Table A-8. Sv/L by Analyte and ULD, DST Liquid Samples

\begin{tabular}{|l|l|l|l|l|}
\hline \multicolumn{1}{|c|}{ Tank } & \multicolumn{1}{|c|}{${ }^{137} \mathrm{Cs}$} & \multicolumn{1}{c|}{ Alpha } & \multicolumn{1}{c|}{${ }^{90} \mathrm{Sr}+{ }^{90} \mathbf{Y}$} & ULD \\
\hline $241-\mathrm{AN}-101$ & $3.24 \mathrm{E}+01$ & $1.71 \mathrm{E}-01$ & $5.18 \mathrm{E}-01$ & $3.31 \mathrm{E}+01$ \\
\hline $241-\mathrm{AN}-102$ & $1.17 \mathrm{E}+02$ & $7.82 \mathrm{E}+02$ & $2.10 \mathrm{E}+02$ & $1.11 \mathrm{E}+03$ \\
\hline $241-\mathrm{AN}-103$ & $2.51 \mathrm{E}+02$ & $2.56 \mathrm{E}+02$ & $5.15 \mathrm{E}-02$ & $5.07 \mathrm{E}+02$ \\
\hline $241-\mathrm{AN}-104$ & $2.09 \mathrm{E}+02$ & $5.45 \mathrm{E}+01$ & $3.24 \mathrm{E}-01$ & $2.64 \mathrm{E}+02$ \\
\hline $241-\mathrm{AN}-105$ & $1.28 \mathrm{E}+02$ & $1.26 \mathrm{E}+02$ & $1.03 \mathrm{E}-01$ & $2.55 \mathrm{E}+02$ \\
\hline $241-\mathrm{AN}-107$ & $1.16 \mathrm{E}+02$ & $3.63 \mathrm{E}+03$ & $2.51 \mathrm{E}+02$ & $3.99 \mathrm{E}+03$ \\
\hline $241-\mathrm{AP}-101$ & $5.15 \mathrm{E}+01$ & $2.64 \mathrm{E}-02$ & $3.30 \mathrm{E}-01$ & $5.19 \mathrm{E}+01$ \\
\hline $241-\mathrm{AP}-102$ & $7.19 \mathrm{E}+01$ & $1.93 \mathrm{E}+00$ & $3.59 \mathrm{E}+00$ & $7.74 \mathrm{E}+01$ \\
\hline $241-\mathrm{AP}-103$ & $2.09 \mathrm{E}+00$ & $1.91 \mathrm{E}-02$ & $1.74 \mathrm{E}-02$ & $2.12 \mathrm{E}+00$ \\
\hline $241-\mathrm{AP}-104$ & $1.59 \mathrm{E}+00$ & $1.46 \mathrm{E}+00$ & $2.05 \mathrm{E}-01$ & $3.25 \mathrm{E}+00$ \\
\hline $241-\mathrm{AP}-105$ & $6.70 \mathrm{E}+01$ & $4.47 \mathrm{E}+01$ & $5.12 \mathrm{E}-01$ & $1.12 \mathrm{E}+02$ \\
\hline $241-\mathrm{AP}-106$ & $1.27 \mathrm{E}+01$ & $1.62 \mathrm{E}+00$ & $3.82 \mathrm{E}-01$ & $1.47 \mathrm{E}+01$ \\
\hline $241-\mathrm{AP}-107$ & $3.82 \mathrm{E}+00$ & $4.12 \mathrm{E}-01$ & $1.15 \mathrm{E}-01$ & $4.35 \mathrm{E}+00$ \\
\hline $241-\mathrm{AP}-108$ & $1.78 \mathrm{E}+01$ & $8.85 \mathrm{E}-01$ & $4.84 \mathrm{E}-01$ & $1.92 \mathrm{E}+01$ \\
\hline $241-\mathrm{AW}-101$ & $1.24 \mathrm{E}+02$ & $3.48 \mathrm{E}+01$ & $7.24 \mathrm{E}-01$ & $1.59 \mathrm{E}+02$ \\
\hline $241-\mathrm{AW}-102$ & $1.13 \mathrm{E}+01$ & $7.46 \mathrm{E}+00$ & $5.19 \mathrm{E}-01$ & $1.92 \mathrm{E}+01$ \\
\hline $241-\mathrm{AW}-103$ & $6.58 \mathrm{E}+00$ & $4.38 \mathrm{E}-02$ & $5.44 \mathrm{E}-04$ & $6.62 \mathrm{E}+00$ \\
\hline $241-\mathrm{AW}-104$ & $1.45 \mathrm{E}+00$ & $1.97 \mathrm{E}+01$ & $1.93 \mathrm{E}-02$ & $2.12 \mathrm{E}+01$ \\
\hline $241-\mathrm{AW}-105$ & $4.50 \mathrm{E}+00$ & $8.14 \mathrm{E}+00$ & $1.61 \mathrm{E}-01$ & $1.28 \mathrm{E}+01$ \\
\hline $241-\mathrm{AW}-106$ & $5.93 \mathrm{E}+01$ & $1.27 \mathrm{E}+02$ & $9.47 \mathrm{E}-01$ & $1.88 \mathrm{E}+02$ \\
\hline $241-\mathrm{AY}-101$ & $2.81 \mathrm{E}+01$ & $2.82 \mathrm{E}+02$ & $4.69 \mathrm{E}+00$ & $3.15 \mathrm{E}+02$ \\
\hline $241-\mathrm{AY}-102$ & $1.15 \mathrm{E}+00$ & $2.30 \mathrm{E}+00$ & $2.94 \mathrm{E}+00$ & $6.39 \mathrm{E}+00$ \\
\hline $241-\mathrm{SY}-101$ & $2.89 \mathrm{E}+02$ & $1.65 \mathrm{E}+02$ & $3.80 \mathrm{E}+00$ & $4.58 \mathrm{E}+02$ \\
\hline $241-\mathrm{SY}-102$ & $9.74 \mathrm{E}+00$ & $1.00 \mathrm{E}+02$ & $6.11 \mathrm{E}-01$ & $1.11 \mathrm{E}+02$ \\
\hline $241-\mathrm{SY}-103$ & $1.27 \mathrm{E}+02$ & $8.31 \mathrm{E}+00$ & $6.67 \mathrm{E}+00$ & $1.42 \mathrm{E}+02$ \\
\hline & & & & \\
\hline
\end{tabular}


Table A-9. Comparison of Observed and Estimated ULD Quantiles for SSTs

\begin{tabular}{|c|c|c|c|c|}
\hline \multirow[b]{2}{*}{$\begin{array}{l}\text { Percentile } \\
\text { Point }\end{array}$} & \multicolumn{2}{|c|}{ SST Solid Samples } & \multicolumn{2}{|c|}{ SST Liquid Samples } \\
\hline & $\begin{array}{l}\text { Observed } \\
\text { Quantile }\end{array}$ & $\begin{array}{l}\text { Lognormal } \\
\text { Quantile }\end{array}$ & $\begin{array}{l}\text { Observed } \\
\text { Quantile }\end{array}$ & $\begin{array}{l}\text { Lognormal } \\
\text { Quantile }\end{array}$ \\
\hline $0 \%$ & 76 & NA & 0 & NA \\
\hline $5 \%$ & 336 & 166 & 10 & 6 \\
\hline $10 \%$ & 484 & 302 & 28 & 12 \\
\hline $15 \%$ & 572 & 452 & 81 & 19 \\
\hline $20 \%$ & 824 & 623 & 94 & 27 \\
\hline $25 \%$ & 921 & 821 & 116 & 37 \\
\hline $30 \%$ & 1010 & 1051 & 124 & 49 \\
\hline $35 \%$ & 1335 & 1322 & 133 & 64 \\
\hline $40 \%$ & 1580 & 1643 & 139 & 81 \\
\hline $45 \%$ & 1705 & 2028 & 148 & 103 \\
\hline $50 \%$ & 2000 & 2495 & 157 & 131 \\
\hline $55 \%$ & 2655 & 3069 & 160 & 165 \\
\hline $60 \%$ & 2890 & 3788 & 164 & 210 \\
\hline $65 \%$ & 3505 & 4708 & 168 & 269 \\
\hline $70 \%$ & 4510 & 5921 & 180 & 349 \\
\hline $75 \%$ & 5275 & 7582 & 196 & 462 \\
\hline $80 \%$ & 5940 & 9986 & 214 & 631 \\
\hline $85 \%$ & 8070 & 13767 & 271 & 909 \\
\hline $90 \%$ & 22600 & 20619 & 630 & 1437 \\
\hline $95 \%$ & 73300 & 37521 & 3821 & 2837 \\
\hline $100 \%$ & 173000 & $\mathrm{NA}$ & 4590 & $\mathrm{NA}$ \\
\hline
\end{tabular}


Table A-10. Comparison of Observed and Estimated ULD Quantiles for DSTs

\begin{tabular}{|c|c|c|c|c|c|c|c|c|}
\hline \multirow{2}{*}{$\begin{array}{c}\text { Percentile } \\
\text { Point }\end{array}$} & \multicolumn{2}{|c|}{ DST Solid Samples } & \multicolumn{2}{l|}{ DST Liquid Samples } & \multicolumn{2}{c|}{$\begin{array}{c}\text { DST Solid Samples, } \\
\text { without AY Tanks }\end{array}$} & $\begin{array}{c}\text { DST Liquid Samples, } \\
\text { without AY Tanks }\end{array}$ \\
\cline { 2 - 10 } & $\begin{array}{c}\text { Observed } \\
\text { Quantile }\end{array}$ & $\begin{array}{c}\text { Lognormal } \\
\text { Quantile }\end{array}$ & $\begin{array}{c}\text { Observed } \\
\text { Quantile }\end{array}$ & $\begin{array}{c}\text { Lognormal } \\
\text { Quantile }\end{array}$ & $\begin{array}{c}\text { Observed } \\
\text { Quantile }\end{array}$ & $\begin{array}{c}\text { Loguormal } \\
\text { Quantile }\end{array}$ & $\begin{array}{c}\text { Observed } \\
\text { Quantile }\end{array}$ & $\begin{array}{c}\text { Lognormal } \\
\text { Quantile }\end{array}$ \\
\hline $0 \%$ & 261 & NA & 2 & NA & 261 & NA & 2 & NA \\
\hline $5 \%$ & 349 & 166 & 3 & 2 & 335 & 246 & 3 & 3 \\
\hline $10 \%$ & 446 & 352 & 5 & 5 & 408 & 416 & 5 & 5 \\
\hline $15 \%$ & 561 & 583 & 7 & 8 & 504 & 593 & 8 & 8 \\
\hline $20 \%$ & 919 & 872 & 12 & 12 & 599 & 787 & 14 & 12 \\
\hline $25 \%$ & 1400 & 1230 & 15 & 16 & 1000 & 1002 & 17 & 17 \\
\hline $30 \%$ & 1592 & 1677 & 19 & 22 & 1400 & 1244 & 19 & 22 \\
\hline $35 \%$ & 2278 & 2234 & 20 & 28 & 1560 & 1521 & 21 & 29 \\
\hline $40 \%$ & 3952 & 2933 & 28 & 37 & 1720 & 1841 & 31 & 38 \\
\hline $45 \%$ & 4842 & 3818 & 48 & 47 & 3115 & 2215 & 50 & 48 \\
\hline $50 \%$ & 5340 & 4947 & 77 & 60 & 4510 & 2656 & 77 & 62 \\
\hline $55 \%$ & 5796 & 6411 & 111 & 77 & 4925 & 3185 & 111 & 79 \\
\hline $60 \%$ & 6524 & 8344 & 124 & 98 & 5340 & 3831 & 118 & 101 \\
\hline $65 \%$ & 7796 & 10954 & 152 & 127 & 5720 & 4637 & 147 & 130 \\
\hline $70 \%$ & 10012 & 14595 & 182 & 166 & 6100 & 5670 & 171 & 170 \\
\hline $75 \%$ & 12700 & 19891 & 255 & 222 & 7160 & 7044 & 222 & 228 \\
\hline $80 \%$ & 16900 & 28081 & 274 & 308 & 8220 & 8969 & 260 & 315 \\
\hline $85 \%$ & 25660 & 41970 & 372 & 449 & 10460 & 11888 & 400 & 459 \\
\hline $90 \%$ & 43540 & 69591 & 487 & 723 & 12700 & 16944 & 497 & 739 \\
\hline $95 \%$ & 214900 & 147248 & 989 & 1464 & 16200 & 28653 & 1050 & 1495 \\
\hline $100 \%$ & 463000 & NA & 3990 & NA & 19700 & NA & 3990 & NA \\
\hline
\end{tabular}


HNF-4534 Rev. 0

A-12 
HNF-4534 Rev. 0

\section{APPENDIX B}

INDEPENDENT REVIEW

B-1 
HNF-4534 Rev. 0

B-2 


\section{REVIEW CHECKLIST}

Document Reviewed:

Sample Based Unit hiter Dose Estimates, HNF-453\%, Revo

Scope of Review:

Check of Statistical Calculations and conversines of number valuas

Yes No NA

$\Varangle 0 \mathrm{O}$ * Previous reviews complete and cover analysis, up to scope of this review, with no gaps.

$\circledast 0 \bigcirc$ Problem completely defined.

$\bigcirc \quad$ Accident scenarios developed in a clear and logical manner.

$\notin \bigcirc \bigcirc \quad$ Necessary assumptions explicitly stated and supported.

$\otimes \bigcirc \bigcirc$ Computer codes and data files documented.

$\notin \bigcirc \bigcirc$ Data used in calculations explicitly stated in document.

$\otimes \bigcirc$ Data checked for consistency with original source information as applicable.

$\bigcirc \bigcirc$ Mathematical derivation checked including dimensional consistency of results.

$\notin 0$ Models appropriate and used within range of validity or use outside range of established $\otimes \bigcirc \quad \mu^{b} \begin{aligned} & \text { validity justified. } \\ & \text { Hand calculations checked for errors. Spreadsheet results should be treated exactly the }\end{aligned}$

$\otimes 0 \quad 0 \quad$ Software input correct and consistent with document reviewed.

\& $\bigcirc$ Software output consistent with input and with results reported in document reviewed.

$\bigcirc \quad$ Limits/criteria/guidelines applied to analysis results are appropriate and referenced. Limits/criteria/guidelines checked against references.

$\bigcirc \oslash$ Safety margins consistent with good engineering practices.

$\otimes \bigcirc \quad$ Conclusions consistent with analytical results and applicable limits.

$\otimes 0 \quad$ Results and conclusions address all points required in the problem statement.

$\bigcirc \varnothing$ Format consistent with appropriate NRC Regulatory Guide or other standards.

$\bigcirc \bigcirc *$ Review calculations, comments, and/or notes are attached.

60 Document approved.
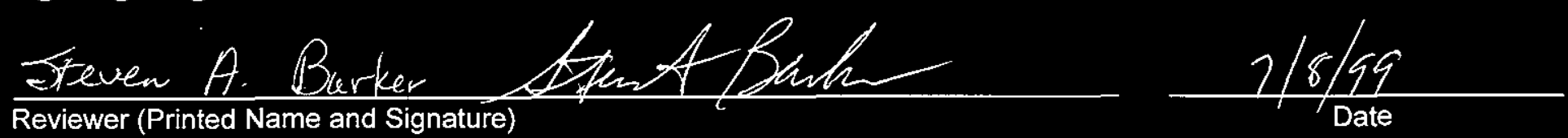

*Any calculations, comments, or notes generated as part of this review should be signed, dated and attached to this checklist. Such material should be labeled and recorded in such a manner as to be intelligible to a technically qualified third party. 


\section{DISTRIBUTION SHEET}

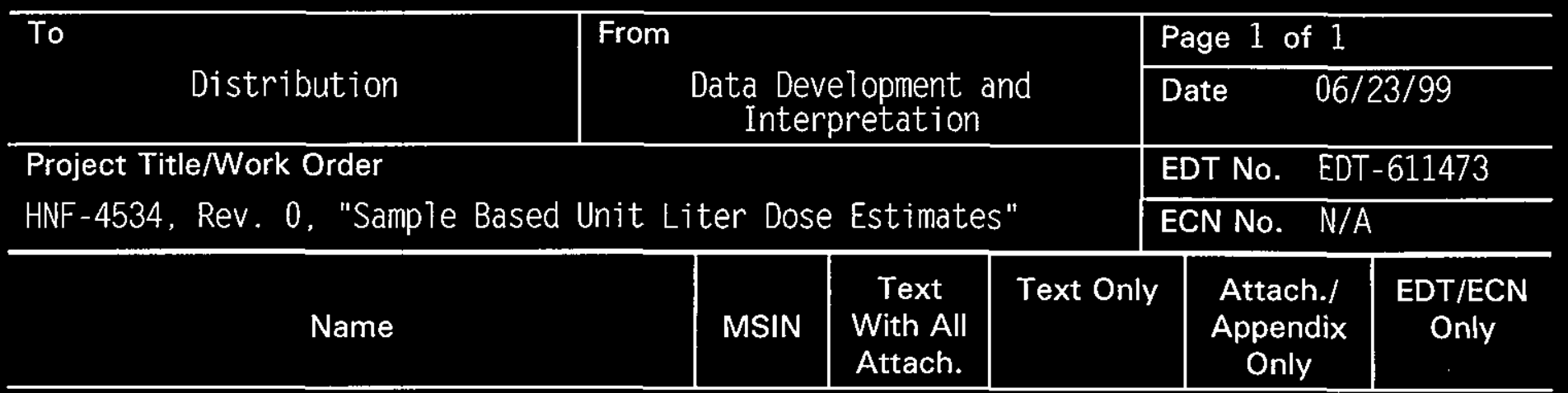

Fluor Daniel Northwest

B. E. Hey

J. C. VanKeuren

B4-47

B4- 47

$x$
$x$

Lockheed Martin Hanford, Corp.
S. A. Barker
W. L. Cowley
J. S. Davis
C. DeFigh-Price
G. W. Gault
K. M. Hall
L. Jensen
J. E. Meacham
D. A. Reynolds
S. R. Wilmarth
T.C.S.R.C.

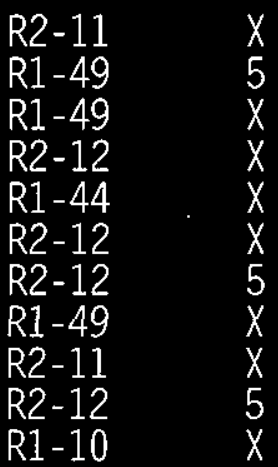

Lockheed Martin Services, Inc. Central Files

B1-07 $\quad X$

